University of Nebraska - Lincoln

DigitalCommons@University of Nebraska - Lincoln

\title{
Effects of Habitat Management Treatments on Plant Community Composition and Biomass in a Montane Wetland
}

Jane E. Austin

U.S. Geological Survey, jaustin@usgs.gov

Janet R. Keough

U.S. Geological Survey

William H. Pyle

U.S. Fish and Wildlife Service

Follow this and additional works at: https://digitalcommons.unl.edu/usgsnpwrc

Part of the Other International and Area Studies Commons

Austin, Jane E.; Keough, Janet R.; and Pyle, William H., "Effects of Habitat Management Treatments on Plant Community Composition and Biomass in a Montane Wetland" (2007). USGS Northern Prairie Wildlife Research Center. 1.

https://digitalcommons.unl.edu/usgsnpwrc/1

This Article is brought to you for free and open access by the US Geological Survey at DigitalCommons@University of Nebraska - Lincoln. It has been accepted for inclusion in USGS Northern Prairie Wildlife Research Center by an authorized administrator of DigitalCommons@University of Nebraska - Lincoln. 


\title{
EFFECTS OF HABITAT MANAGEMENT TREATMENTS ON PLANT COMMUNITY COMPOSITION AND BIOMASS IN A MONTANE WETLAND
}

\author{
Jane E. Austin ${ }^{1}$, Janet R. Keough ${ }^{1,2}$, and William H. Pyle ${ }^{3,4}$ \\ ${ }^{1}$ U.S. Geological Survey \\ Northern Prairie Wildife Research Center \\ 8711 37th Street $S E$ \\ Jamestown, North Dakota, USA 58401 \\ E-mail: jane_austin@usgs.gov \\ ${ }^{2}$ Environmental Protection Agency \\ Mid-continental Ecological Division \\ National Health and Environmental Effects Research Laboratory \\ 6201 Congdon Boulevard \\ Duluth, Minnesota, USA 55804-2595 \\ ${ }^{3}$ U.S. Fish and Wildlife Service \\ Grays Lake National Wildlife Refuge \\ Wayan, Idaho, USA 83285 \\ ${ }^{4}$ Present address: \\ U.S. Fish and Wildlife Service \\ Kodiak National Wildlife Refuge \\ 1390 Buskin River Road \\ Kodiak, Alaska, USA 99615
}

\begin{abstract}
Grazing and burning are commonly applied practices that can impact the diversity and biomass of wetland plant communities. We evaluated the vegetative response of wetlands and adjacent upland grasslands to four treatment regimes (continuous idle, fall prescribed burning followed by idle, annual fall cattle grazing, and rotation of summer grazing and idle) commonly used by the U.S. Fish and Wildlife Service. Our study area was Grays Lake, a large, montane wetland in southeastern Idaho that is bordered by extensive wet meadows. We identified seven plant cover types, representing the transition from dry meadow to deep wetland habitats: mixed deep marsh, spikerush slough, Baltic rush (Juncus balticus), moist meadow, alkali, mesic meadow, and dry meadow. We compared changes in community composition and total aboveground biomass of each plant cover type between 1998, when all units had been idled for three years, and 1999 ( 1 yr post-treatment $)$ and 2000 ( 2 yr post-treatment). Analysis using non-metric multidimensional scaling indicated that compositional changes varied among cover types, treatments, and years following treatment. Treatment-related changes in community composition were greatest in mixed deep marsh, Baltic rush, and mesic meadow. In mixed deep marsh and Baltic rush, grazing and associated trampling contributed to changes in the plant community toward more open water and aquatic species and lower dominance of Baltic rush; grazing and trampling also seemed to contribute to increased cover in mesic meadow. Changing hydrological conditions, from multiple years of high water to increasing drought, was an important factor influencing community composition and may have interacted with management treatments. Biomass differed among treatments and between years within cover types. In the wettest cover types, fall burning and grazing rotation treatments had greater negative impact on biomass than the idle treatment, but in drier cover types, summer grazing stimulated biomass production. Our results illustrate the spatial and temporal complexity of the transition between dry meadow and wetland habitats, and variable interactions among plant communities, treatments, and annual wetland conditions.
\end{abstract}

Key Words: environmental gradient, grazing, hydrology, Idaho, idle, prescribed burning 


\section{INTRODUCTION}

Montane wetland systems in the Rocky Mountains support diverse plant communities and provide valuable habitat for breeding waterbirds and other wildlife (Windell et al. 1986, Gammonley 1996, Sanders 1997, Austin and Pyle 2004). Montane wetlands are frequently used to provide food and water resources for domestic livestock during summer and fall. Herbaceous biomass of mesic and wet meadows is high compared to upland habitats (Patton and Judd 1970, Roath and Krueger 1982, Kauffman et al. 1983, Ratliff and Westfall 1987) and hence valued by ranchers. Despite their ecological significance and value to wildlife and livestock, scientific information on effects of grazing on wetland communities is limited and most often focused on plant communities dominated by Poa pratensis or common rhizomatous Carex species. Scientific information on the effects of burning wetlands is even more limited. Moreover, reliability of many grazing studies has been questioned because of the lack of sound study design (Kirby et al. 1992). Studies of the impacts of grazing on montane wetlands have largely focused on riparian wet meadows in the southern Rockies (Ratliff and Westfall 1987, Schulz and Leininger 1990, Hoff 1993, Humphrey and Patterson 2000) or the Great Basin (Martin and Chambers 2001). Fewer studies have been conducted in the central Rockies (Leege et al. 1981, Roath and Krueger 1982), and fewer still have examined the impact of burning on montane wetlands (Boyd et al. 1993). The use of prescribed burning as a restoration and management tool for wetlands is receiving increased interest among land managers. Characteristics of montane wetlands and their responses to grazing or other management practices are often spatially and temporally variable, driven largely by precipitation and hydrology (Kauffman et al. 1983, Windell et al. 1986, Dobkin et al. 1998, Martin and Chambers 2001). Therefore, information from a variety of montane wetlands is needed to understand variations and commonalities in the communities and their responses to manipulations, and for adapting habitat management practices to local conditions.

Grays Lake, located in southeast Idaho (Figure 1), is one of the largest contiguous, palustrine wetlands in the western United States. Due to its montane location (1,946 m elevation), large size (15,000 ha), and topographic variation, it supports a valuable diversity of animal and plant species and thus is of regional importance. Grays Lake includes extensive areas of intermittently to semipermanently flooded wetland bordering a central Typha

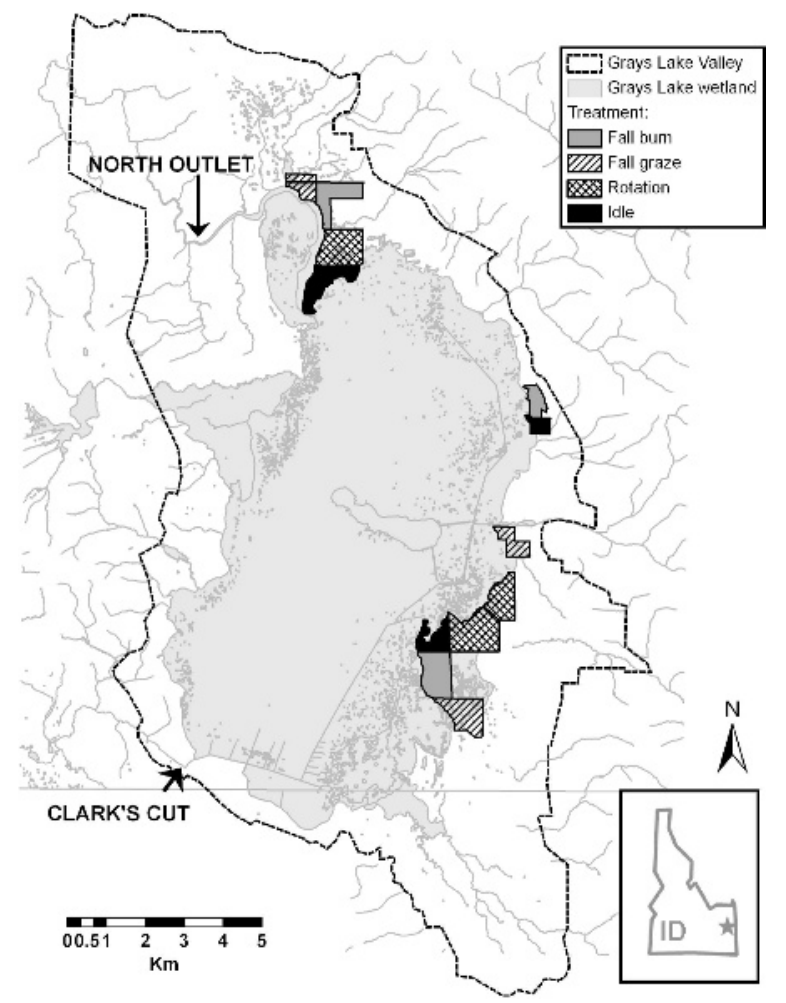

Figure 1. Location of experimental fields and treatment applications on Grays Lake National Wildlife Refuge, Idaho, 1997-2000. Outflows from the basin are via Clark's Cut and the North Outlet.

latifolia-Schoenoplectus tabernaemontani marsh. A large proportion of the wetland habitat of Grays Lake is encompassed within Grays Lake National Wildlife Refuge (GLNWR), established in 1965 to protect and restore habitat for waterfowl production, foraging waterbirds, sandhill cranes, and other wildlife (U.S. Fish and Wildlife Service 1982). Refuge management is focused on the upland and wetland habitats that border the contiguous interior marsh; grazing, haying, and burning are the most common methods of vegetation management. Local ranchers also periodically burn to manage vegetation in wet meadow and upland areas on their lands.

We conducted a study from 1997-2000 to investigate the vegetation response to different management regimes in wetlands and adjacent grasslands at GLNWR. By sampling across the topographic gradient of Grays Lake, from dry meadows to the edge of the interior deep marsh, we sought to determine the relationship between the hydrologic gradient and cover type composition, and the relationship between vegetation responsiveness and management practices. Habitat manage- 
ment practices (treatments) were selected by refuge staff as those of greatest interest for management applications and included continuous idle, fall graze, fall burn, and rotation of idle and summer grazing. Our objectives were to 1) categorize and describe plant communities (cover types) along the transition from dry meadow to deep emergent wetland and to 2) determine short-term changes in community composition and biomass of plant cover types in response to the four management regimes.

\section{METHODS}

\section{Study Area}

Grays Lake lies within the Caribou Range of the Rocky Mountains in southeast Idaho, at the western edge of the Greater Yellowstone Ecosystem (Marston and Anderson 1991) (Figure 1). The central portion of this montane wetland is a large, contiguous area of permanently and semipermanently flooded wetland dominated by $S$. tabernaemontani and lesser amounts of T. latifolia (8,854 ha; hereafter interior deep marsh). The habitats surrounding the interior deep marsh (lakeshore) are a mosaic of seasonally (2,251 ha) and temporarily flooded (3,602 ha) habitats, variously dominated by Carex spp., Eleocharis spp., Juncus balticus, Deschampsia caespitosa, P. pratensis, Bromus inermis, and Muhlenbergia richardsonis. Most of the lakeshore habitat is $<1 \mathrm{~m}$ deep when flooded. Most soils are silty loam or loam (Austin et al. 2004). Because of its high elevation and northern latitude, the valley is subject to severe and prolonged winters, with snow accumulations often exceeding $200 \mathrm{~cm}$. Temperatures range from $-45^{\circ} \mathrm{C}$ during winter to $35^{\circ} \mathrm{C}$ during summer, but freezing temperatures can occur during any month. The weather station in nearby Henry, Idaho, located $13 \mathrm{~km}$ southwest of Grays Lake and at 1,869 m elevation, had an average annual precipitation of $53.5 \mathrm{~cm}$ and average annual snow accumulation of $219 \pm 29$ (SD) cm (1971-2000; Western Region Climate Center 2002).

Most of the valley has been impacted by human activities since the 1860 s, primarily by season-long grazing by cattle, but also by annual haying, smallscale irrigation and drainage, and some cultivation for gardens and small grains (primarily in drier sites). Introduced species such as B. inermis, Phleum pratense, Alopecurus pratensis, and Trifolium pratense were probably seeded by private landowners in the 1940s and 1950s, or introduced via cultivated hay brought in from elsewhere. Most cultivated areas were $>1 \mathrm{~km}$ from the areas we studied (Steel
1952). Since establishment of the refuge, cattle grazing and haying have been the dominant land uses. Development of dikes and levees by the refuge in the 1960s and 1970s included seeding of the introduced species Phalaris arundinacea, $P$. pratense, and $B$. inermis. Some previously cultivated fields were seeded with Phleum pretense, cultivated Bromus varieties, $A$. arundinaceus, Dactylis glomerata, and various Trifolium varieties. Herbicides were used in various fields to control Circium arvense and other weeds; one study field was treated in the 1980s, which may have affected other forbs.

The water level of Grays Lake is determined by precipitation, evapotranspiration, and water-level management at two outflows. During May, the lake level is high enough to flood the surrounding lakeshore habitats. Since 1965, the lake has been typically drawn down to a standard level from late June-September to supply water for irrigation downstream, leaving surface water only in the interior deep marsh and in isolated, groundwaterfed sloughs. Only in very wet years is standing water available in the margins between $J$. balticus-Carex habitat and the interior deep marsh during summer months. Soil moisture in some areas is also influenced by seeps and subsurface irrigation. Patches of soil with whitened salt deposits are found sporadically, attesting to evapotranspiration of subsurface groundwater. Such patches are typically associated with "alkali"-tolerant plant species such as $M$. richardsonis and Symphyotrichum ascendens.

All of the interior marsh and most of the surrounding wetlands are contained within the approved boundary for GLNWR; about half of the wetlands are under refuge control. Plant communities of dry meadows averaged $10 \%$ of area of fields we studied and were dominated by $P$. pratensis, Bromus inermis, D. caepitosa, and $M$. richardsonis. Wet meadows (temporarily and seasonally flooded wetland) averaged $76 \%$ of field area studied and were characterized by alkali-tolerant species (e.g., Hordeum brachyantherum, Juncus spp., Eleocharis palustris, Carex atherodes, C. nebrascensis, C. praegracilis, and C. utriculata). Semipermanently flooded wetland averaged $12 \%$ of field areas studied and was characterized by $S$. tabernaemontani and T. latifolia. See Austin et al. (2004) for a complete description of plant communities and hydrology.

\section{Study design}

We selected 12 of 22 fields (21-121 ha) administered by the U.S. Fish and Wildlife Service (USFWS) and bordering the interior deep marsh 
(Figure 1). The gradient of plant communities within each field typically spanned from dry meadow to semipermanently flooded wetland communities and extended $\sim 25-50 \mathrm{~m}$ into the interior deep marsh, abutting stands of tall emergents (cattail or bulrush) or open water. Elevations of fields averaged 1,946.9 $\pm 1.0 \mathrm{~m}(\mathrm{SD})$ (range 1,945.5$1,960.1 \mathrm{~m})$. The 22 fields were assigned one of three lakeshore classifications (field bordered by open water, tall emergent vegetation, or interspersions of open water and tall emergent vegetation). We used lakeshore configuration as a blocking criterion and randomly assigned treatment types within each group of lakeshore classes, with three replicates for each of the four treatments: continuous idle (i.e., no treatment), fall burned followed by idle (fall burn), annually fall grazed (fall graze), and summer grazed followed by idle (rotation). All fields were left idle from 1996 to the summer of 1998 (before first treatment) to allow vegetative structure and litter to become more comparable among fields. We collected pre-treatment data during 1997 and 1998, when all fields remained idle. We applied grazing and burning treatments after data had been collected in 1998. Idle fields were untreated from 1997-2000. Fall burns were conducted over two days in late October 1998 using a ring fire, with objectives of burning $100 \%$ of residual grass and rush vegetation on dry meadows to seasonally flooded areas and $40 \%-60 \%$ of tall emergent vegetation in semipermanently flooded areas. Fall-burned fields were untreated (idle) in 1999 and 2000. The fall-graze treatment consisted of cattle grazing from early September to late October in 1998 and 1999 using 2.3-2.5 animal unit months (AUM)/ha, with the objective of removing $\geq 40 \%$ of total annual biomass on $\geq 80 \%$ of the field area. The grazing rotation treatment consisted of cattle grazing from early July through August 1998 using 2.3 AUM/ha, with objectives of removing $\geq 60 \%$ of total annual biomass from $\geq 80 \%$ of temporarily flooded areas and removing $10 \%$ of annual biomass from seasonally flooded (rush-sedge) areas. Grazing rotation fields were idled in 1999 and 2000. We collected post-treatment data in 1999 and 2000.

\section{Sampling methods}

We evaluated if treatments achieved prescription objectives immediately after the treatment was completed. We conducted visual ground and aerial examination of each burn field to determine percent burned. For grazed fields, we estimated the proportion of aboveground biomass removed using five forage-use classes (following Anderson and Currier
1973): 1) none (0\%-15\% vegetation removed, little evidence of grazing use); 2) low (16\%-35\% vegetation removed; site maintains patchy appearance with moderate use of most palatable species and little use of species of low palatability); 3) moderate (36\%$65 \%$ vegetation removed, site has patchy appearance with high use of most palatable species and light use of species of low palatability); 4) high (66\%-80\% vegetation removed, very high use of most palatable species, moderate use of least palatable species); and $5)$ very high ( $80 \%$ vegetation removed, most of current year's growth removed, residual stubble mostly $\leq 10 \mathrm{~cm}$ height). We estimated proportion of annual biomass removed, classified and mapped areas of each forage-use class in the field with the aid of a geographic positioning system (GPS) receiver (Anderson and Currier 1973), overlaid the digitized data with wetland classification data in a geographic information system, and estimated percent of area, by field and flooding regime (temporarily, seasonally, or semipermanently flooded), that fell in each forage use class. This approach allowed us to roughly quantify immediate success of treatment application relative to treatment objectives and later impacts.

Within each field, we established permanent transects that were consistently oriented along a south-to-north compass heading and $210 \mathrm{~m}$ apart. With this layout, transects spanned the topographic gradient of each field and ensured a relatively uniform coverage of the entire field. Along each transect, we established permanent sample points every $50 \mathrm{~m}$, oriented $1 \mathrm{~m}$ west of each transect line. Numbers of transects ranged from two-seven, and sampling points in each field varied depending on field dimensions. Thus, total number of sampling points varied among treatments (idle $=126$; fall graze $=158$; rotation $=$ 223; fall burn $=193$ ). We marked transect ends with steel t-posts, and each sampling point was marked with a long spike with a large metal washer that could be relocated using a metal detector in subsequent years. We measured the absolute elevation of each sampling point using laser survey technology and secondary benchmarks established by the USFWS Realty Office; elevations for benchmarks were tied to existing U.S. Geological Survey benchmarks. Elevation measurements also were taken of the lake basin level and referenced back to permanent water-level gauges located at the southern end of Grays Lake. We used waterlevel data collected over 21 years (1979-2000; USFWS, unpublished data) to relate plant communities to spring high water levels. We excluded water-level data from one field in the fall grazing 
treatment because of apparent errors in the elevation data.

We used the line-intercept method to assess plant species cover in the plots in 1998, 1999, and 2000 (Brower et al. 1990, Mitchell and Hughes 1995). We anchored a 2-m rod, subdivided into $5-\mathrm{cm}$ intervals, at the sampling point, and extended it horizontally, perpendicular (west) to the permanent transect line, but offset by $1 \mathrm{~m}$ to avoid disturbance associated with the transect line. Sampling occurred as close to the peak of growth as possible (late June-July). Within each 5-cm interval along the 2m length, we recorded the vegetation that touched the rod (for individual grass stems and most sedges) or whose canopy's vertical projection intercepted the rod (for tussocks, shrubs, and species with an extended canopy). We similarly recorded any bare (unvegetated) soil or standing water for each interval.

We developed a comprehensive list of all plant species encountered during line-intercept sampling; taxonomy applied in the field followed Hitchcock (1973) and Cronquist et al. (1992-1994). Common and scientific names in this paper follow the most current accepted taxonomy as recorded in the Integrated Taxonomic Information System on-line database (retrieved December 2003 from http:// www.itis.usda.gov). Voucher specimens were collected for most vascular plant species in the study fields and verified by regional experts. Replicate material for each specimen was deposited in the GLNWR Herbarium (Wayan, Idaho).

We estimated the current year aboveground biomass annually from plots located $1 \mathrm{~m}$ away from the west end of the plant-cover line transects and at $45^{\circ}$ angles apart each year. At each point, a $0.25-\mathrm{m}^{2}$ plot was created using a three-sided frame with the fourth side formed by a meter stick. We clipped all live biomass from within the frame; samples were later oven-dried at $60^{\circ} \mathrm{C}$ to a constant mass and weighed to the nearest $0.1 \mathrm{~g}$. When woody stems occurred in the clip plots, we clipped only new growth. This method minimized the influence of trampling and the effects of the previous year's sample; however, because the sample plots were offset from the plant cover line transects, habitat variation sometimes resulted in slight differences in species composition between the two sampling methods. Hereafter, we refer to each combination of plant-cover line transect and biomass plots as plots.

We collected soil samples in September 2000 to evaluate relationships between various soil features and the plant community. Soils were sampled along the length of the vegetation survey plots in each unit.
Plots selected for soil sampling were distributed evenly across plant cover types and treatments; we sought to target five to six samples per cover type per treatment, except on dry meadow sites (no samples taken). At each site, we sampled the upper $10 \mathrm{~cm}$ of soil using a $1-\mathrm{cm}$ diameter soil auger. We shipped frozen samples for laboratory analysis at the Utah State University Analytical Laboratories in Logan, Utah. We used standard methods to determine conductivity and percent of sand, silt, and clay. We determined percent organic matter using the loss-on-ignition method.

\section{Data Analyses}

We assigned each of the 698 plots to plant cover types using cluster analysis of the plant cover data collected in 1998 (two plots were dropped: one on a road and one on private land). We used Wards Method in PC-ORD (McCune and Mefford 1999) for hierarchical clustering, also known as the "error sum of squares" method (Wishart 1969, GreigSmith 1983). Before analysis, we removed plant species that were extremely rare (species frequency $<3 \%$ of plots). Cluster analysis yielded seven plant cover types, to which we assigned labels based on dominant species and habitat type: mixed deep marsh, spikerush slough, Baltic rush (J. balticus), moist meadow, alkali, mesic meadow, and dry meadow (Table 1). We inferred environmental conditions from the habitats known for the dominant species (Hitchcock 1973, Cronquist et al. 1992-1994). Overall, 27.2\% ( $\mathrm{n}=190)$ of the 698 plots were classified as mesic meadow, $17.2 \%(\mathrm{n}=$ $120)$ as Baltic rush, $14.2 \%(\mathrm{n}=99)$ as mixed deep marsh, $12.6 \%(\mathrm{n}=88)$ as moist meadow, 6.0\% (n $=42)$ as spikerush, $5.3 \%(\mathrm{n}=37)$ as dry meadow, and $3.3 \%(\mathrm{n}=23)$ as alkali; $14.2 \%(\mathrm{n}=99)$ of the plots were composed of mixtures of species transitional between types and could not be classified.

We used non-metric multidimensional scaling (NMS) ordination analysis (PC-ORD; McCune and Mefford 1999) to examine shifts in community composition due to treatment for each plant cover type. We compared pre- and post-treatment data to identify changes in each plot between years (1998 and 1999, and 1998 and 2000). Because NMS axes are linear, we could estimate within-plot change by subtracting 1998 NMS scores (before treatment) from 1999 or 2000 scores (1 or 2 yr after treatment). We then examined the resulting graphs to see which treatments resulted in "no change" and treatments where change was visible (e.g., difference was positive or negative from 0). We used the Sorenson 
distance measure and assessed three axes in the final solution; selection of axes for interpretation was based on highest incremental $\mathrm{R}^{2}$.

We examined annual differences of biomass (g/ $\mathrm{m}^{2}$ ) within each cover type for all fields (1997 vs. 1998) and for idle fields only (among all $4 \mathrm{yr}$ ) using a one-way analysis of variance (ANOVA), with plot treated as a random variable. We computed least squares means (LSMEANS) to compare among years. To examine treatment effects within each cover type, we compared changes in biomass between sequential years: 1998 and 1999 (1 yr after treatment), 1998 and 2000 (2 yr after treatment), and 1999 and 2000 (2 post-treatment years, when fall-burn and rotation fields were idled and fallgrazed fields were again grazed). The 1998-2000 comparison was included to examine length of treatment impact. We used separate one-way ANOVA for each interval and cover type to evaluate treatment effect and to compute LSMEANS; we assumed plots were independent. We used Student's t-test to determine whether each LSMEAN differed significantly from 0 . We chose to use a one-way ANOVA rather than two-way model with cover type and treatment as two separate factors, because one of the combinations of the two factors (dry meadow habitat for idle treatment) was missing, and we were specifically interested in changes related to the cover type. All analyses were conducted using the mixed models procedure (PROC MIXED) of SAS (SAS Institute, Inc. 1999, 2002) with the significance level of $\alpha=0.05$.

We selected a subsample of soil samples for analysis using plant cover data from 2000, which allowed us to stratify selected samples across cover types and treatments. We conducted a cluster analysis using the July 2000 vegetation cover data to determine cover types for that year's communities, following the same methods as before. This resulted in nine plant cover types that differed slightly from those determined from the 1998 data because abundance of plant species had changed due to climate and treatments. Deep marsh, dominated by $T$. latifolia and $S$. tabernaemontani, was a subset of the 1998 mixed deep marsh, and hairgrass, dominated by $D$. caespitosa, was a subset under the 1998 moist meadow. Soil characteristics were summarized using these nine cover types.

\section{RESULTS}

Results of Treatments

Percent of each field burned averaged $90 \%$ and ranged from $85 \%-98 \%$. Prescribed burning removed most residual graminoid vegetation and litter and met prescription objectives. The three burned fields were effectively devoid of most residual graminoid and litter cover until new vegetation growth was initiated in the following spring. Spatial variation in water conditions affected how vegetation burned, particularly in the wetter habitats. Semipermanently flooded areas (marsh and spikerush slough cover types) had larger portions of their areas within fields unburned $(3 \%, 45 \%$, and $82 \%$ for the 3 fields, respectively). Two percent to $22 \%$ of seasonally flooded areas (Baltic rush, mesic meadow, and alkali) within fields remained unburned, whereas $1 \%-12 \%$ of temporarily flooded areas were unburned. In the southeast part of the basin where water levels were low, sedges bordering the interior deep marsh were senescent and entirely consumed by fire. In contrast, sedges in two fields to the north were partially green due to partial flooding and moist soils, resulting in a patchy, incomplete burn in the marsh cover type and only partial consumption of individual plants by fire.

Cattle consumed $85 \%-95 \%$ of the forage amount targeted in prescription objectives. In the three fields grazed in summer 1998 (rotation fields), moderate forage use occurred on an average of 49 $\pm 11 \%$ [SD] of field area and high use occurred on $17 \pm 25 \%$ of field area; no areas received very high use. In the three fields grazed in fall 1999, moderate forage use occurred on average of $35 \pm 20 \%$ of field area and high use occurred on $19 \pm 26 \%$ of field areas; very high forage use occurred on $5 \pm$ $6 \%$ of field area. In rotation fields, forage use was generally highest in dry meadow and temporarily flooded areas (moderate or high use in $99 \%$ and $88 \%$ of those wetland regimes, respectively), and lower in seasonally flooded (moderate or high use in $62 \%$ of area) and semipermanently flooded areas $(37 \%)$. In fall-grazed fields, livestock use of dry meadow was patchy ( $71 \%$ of area received no or low use and $15 \%$ of area received very high use), as was use of temporarily flooded areas occurring in two fields $(86 \%$ of one field received high use; in the other field, $57 \%$ of the area received high use, 33\% moderate use, and the remaining area low or no use). Forage use was similar among seasonally and semipermanently flooded areas $(51 \%-62 \%$ received moderate or high use, with $<1 \%$ of total area receiving very high use).

\section{Plant Cover Types}

We documented the occurrence of 218 plant species, including 32 grass species, 16 sedge species, eight rush species, 123 forb species, and two woody 
Table 1. Characteristics of eight plant cover types identified by cluster analysis, in transition from dry meadow to wetland habitats, at Grays Lake, Idaho. Number of introduced species (some of which also may be native) are given in parenthesis.

\begin{tabular}{|c|c|c|c|c|c|}
\hline $\begin{array}{l}\text { Cover } \\
\text { type }\end{array}$ & $\begin{array}{c}\text { Characteristics of } \\
\text { location }\end{array}$ & $\begin{array}{l}\text { Flooding } \\
\text { regime }\end{array}$ & $\begin{array}{c}\text { Dominant plant } \\
\text { species }\end{array}$ & $\begin{array}{l}\text { Other characteristic } \\
\text { plant species }\end{array}$ & $\begin{array}{c}\text { No. } \\
\text { species }\end{array}$ \\
\hline $\begin{array}{l}\text { Mixed deep } \\
\text { marsh }\end{array}$ & $\begin{array}{l}\text { At or below the } \\
\text { annual drawdown } \\
\text { elevation } \\
(1,946.15 \mathrm{~m}) \text {, in } \\
\text { standing water or } \\
\text { saturated soils } \\
\text { typically year-round. }\end{array}$ & $\begin{array}{l}\text { Semipermanently } \\
\text { flooded }\end{array}$ & $\begin{array}{l}\text { Carex atherodes, } \\
\text { C. utriculata, } \\
\text { Typha latifolia, } \\
\text { Juncus balticus, } \\
\text { Eleocharis } \\
\text { palustris, } \\
\text { Schoenoplectus } \\
\text { tabernaemontani }\end{array}$ & $\begin{array}{l}\text { Sparganium eurycarpum, } \\
\text { aquatics (Lemna minor, } \\
\text { Potamogeton natans, } \\
\text { Utricularia sp., } \\
\text { Myriophyllum sibiricum, } \\
\text { Mentha arvensis, } \\
\text { Scutellaria galericulata, } \\
\text { Polygonum amphibium) }\end{array}$ & $36(2)$ \\
\hline Spikerush & $\begin{array}{l}\text { Semi-isolated } \\
\text { potholes, } \\
\text { apparently perched } \\
\text { above drawdown } \\
\text { elevation, yet have } \\
\text { standing water in } \\
\text { summer. }\end{array}$ & $\begin{array}{l}\text { Semipermanently } \\
\text { flooded }\end{array}$ & $\begin{array}{l}\text { Eleocharis palustris, } \\
\text { aquatics } \\
\text { (Potamogeton } \\
\text { natans, } \\
\text { Myriophyllum } \\
\text { sibiricum, } \\
\text { Lemna minor) }\end{array}$ & $\begin{array}{l}\text { Juncus balticus, Triglochin } \\
\text { maritimum, Mentha } \\
\text { arvensis, Senecio } \\
\text { hydrophilus, Carex } \\
\text { atherodes, Sium suave }\end{array}$ & $44(2)$ \\
\hline Baltic rush & $\begin{array}{l}\text { Elevations just above } \\
\text { the mixed deep } \\
\text { marsh in soils that } \\
\text { are moist to } \\
\text { saturated during } \\
\text { the growing season. }\end{array}$ & $\begin{array}{l}\text { Seasonally } \\
\text { flooded }\end{array}$ & $\begin{array}{l}\text { Juncus balticus, } \\
\text { Mentha arvensis, } \\
\text { Triglochin } \\
\text { maritimum, } \\
\text { Eleocharis } \\
\text { palustris }\end{array}$ & $\begin{array}{c}\text { Senecio hydrophilus, Carex } \\
\text { praegracilis, C. pellita, } \\
\text { Argentina anserina, } \\
\text { Calamagrostis neglecta, } \\
\text { Deschampsia caespitosa }\end{array}$ & $57(5)$ \\
\hline $\begin{array}{l}\text { Moist } \\
\text { meadow }\end{array}$ & $\begin{array}{l}\text { At the elevation of } \\
\text { median high spring } \\
\text { water level; } \\
\text { apparently flooded } \\
\text { only in early spring. } \\
\text { Soils are typically } \\
\text { not saturated in } \\
\text { summer. }\end{array}$ & $\begin{array}{l}\text { Seasonally and } \\
\text { temporarily } \\
\text { flooded }\end{array}$ & $\begin{array}{l}\text { Carex praegracilis, } \\
\text { Deschampsia } \\
\text { caespitosa }\end{array}$ & $\begin{array}{l}\text { Poa pratensis, Juncus } \\
\text { balticus, Muhlenbergia } \\
\text { richardsonis, } \\
\text { Symphyotrichum } \\
\text { ascendens, Carex } \\
\text { nebrascensis, Valeriana } \\
\text { edulis, Potentilla gracilis } \\
\text { var. flabelliformis, Phleum } \\
\text { pratense, Mentha arvensis, } \\
\text { Achillea millefolium, } \\
\text { Carex pellita }\end{array}$ & $82(11)$ \\
\hline Alkali & $\begin{array}{l}\text { An uncommon cover } \\
\text { type, located in } \\
\text { isolated, shallow } \\
\text { pans; probably } \\
\text { flooded in spring. } \\
\text { Often has a salt } \\
\text { crust in summer } \\
\text { with patches of } \\
\text { bare soil. }\end{array}$ & $\begin{array}{l}\text { Seasonally and } \\
\text { temporarily } \\
\text { flooded }\end{array}$ & $\begin{array}{l}\text { Muhlenbergia } \\
\text { richardsonis, } \\
\text { Symphyotrichum } \\
\text { ascendens, Carex } \\
\text { praegracilis }\end{array}$ & $\begin{array}{l}\text { Juncus balticus, Poa } \\
\text { pratensis, Argentina } \\
\text { anserina, Carex pellita, } \\
\text { Potentilla gracilis var. } \\
\text { flabelliformis }\end{array}$ & $50(6)$ \\
\hline $\begin{array}{l}\text { Mesic } \\
\text { meadow }\end{array}$ & $\begin{array}{l}\text { Above the elevation } \\
\text { of median spring } \\
\text { high water level, } \\
\text { may cover wide } \\
\text { range of higher } \\
\text { elevations. }\end{array}$ & $\begin{array}{l}\text { Temporarily } \\
\text { flooded }\end{array}$ & $\begin{array}{l}\text { Primarily grasses, } \\
\text { especially Poa } \\
\text { pratensis, and forbs }\end{array}$ & $\begin{array}{l}\text { Symphyotrichum ascendens, } \\
\text { Achillea millefolium, } \\
\text { Potentilla gracilis var. } \\
\text { flabelliformis, Phleum } \\
\text { pratense, Cerastium } \\
\text { arvense, Carex } \\
\text { praegracilis, Trifolium } \\
\text { repens, Bromus inermis, } \\
\text { Muhlenbergia richardsonis, } \\
\text { Bromus carinatus, Agoseris } \\
\text { glauca, Astragalus agrestis, } \\
\text { Juncus balticus, } \\
\text { Deschampsia caespitosa, } \\
\text { Taraxacum officinale }\end{array}$ & $101(14)$ \\
\hline
\end{tabular}


Table 1. Continued.

\begin{tabular}{|c|c|c|c|c|c|}
\hline $\begin{array}{l}\text { Cover } \\
\text { type }\end{array}$ & $\begin{array}{c}\text { Characteristics of } \\
\text { location }\end{array}$ & $\begin{array}{l}\text { Flooding } \\
\text { regime }\end{array}$ & $\begin{array}{c}\text { Dominant plant } \\
\text { species }\end{array}$ & $\begin{array}{l}\text { Other characteristic } \\
\text { plant species }\end{array}$ & $\begin{array}{c}\text { No. } \\
\text { species }\end{array}$ \\
\hline $\begin{array}{l}\text { Dry } \\
\text { meadow }\end{array}$ & $\begin{array}{l}\geq 0.6 \mathrm{~m} \text { higher than } \\
\text { average spring high } \\
\text { lake-level. More } \\
\text { common on north } \\
\text { side of Grays Lake } \\
\text { where elevations are } \\
\text { higher. }\end{array}$ & Upland & $\begin{array}{l}\text { Poa pratensis, } \\
\text { Bromus inermis }\end{array}$ & $\begin{array}{l}\text { Lotus tenuis, Achillea } \\
\text { millefolium, } \\
\text { Hesperostipa comata, } \\
\text { Phleum pratense, } \\
\text { Symphyotrichum } \\
\text { ascendens, Medicago } \\
\text { lupulina, Potentilla } \\
\text { gracilis var. } \\
\text { flabelliformis, } \\
\text { Cerastium arvense, } \\
\text { Festuca idahoensis, } \\
\text { Trifolium repens, } \\
\text { Cirsium arvense, } \\
\text { Astragalus agrestis }\end{array}$ & $41(11)$ \\
\hline Unclassified & $\begin{array}{l}\text { Ecotones: mixture of } \\
\text { plant species common } \\
\text { to } \geq 2 \text { cover types } \\
\text { and with no } \\
\text { dominant species. } \\
\text { Relative to site } \\
\text { wetness, this type } \\
\text { most often occurred } \\
\text { between moist } \\
\text { meadow and mesic } \\
\text { meadow. }\end{array}$ & Mixed & $\begin{array}{l}\text { Most often occurred } \\
\text { between moist } \\
\text { meadow and mesic } \\
\text { meadow and } \\
\text { therefore often had } \\
\text { Juncus balticus, } \\
\text { Deschampsia } \\
\text { caespitosa, Carex } \\
\text { nebrascensis, } \\
\text { Eleocharis palustris, } \\
\text { and Hordeum } \\
\text { brachyantherum }\end{array}$ & & \\
\hline
\end{tabular}

species (for complete list, see Austin et al. 2004). Eight grasses and 18 forbs were introduced species, but their occurrence was relatively rare, except for a few regionally common species such as $B$. inermis, C. arvense, and Medicago lupulina. Commonly encountered species considered invasive included $P$. arundinacea, $B$. inermis, $P$. pratensis, and $C$. arvense. Bromus inermis was a common, often dominant species in mesic meadow and dry meadow sites that had a history of cultivation before refuge establishment. Poa pratensis occurred in nearly pure stands.

Figure 2 shows the topographic gradient across plant cover types from mixed deep marsh to dry meadow. Elevations of mixed deep marsh and spikerush plots were similar, with median elevations 0.06-0.09 $\mathrm{m}$ below the annual drawdown level $(1,946.45 \mathrm{~m})$. Mixed deep marsh plots reflect only a narrow edge of the dense, continuous $S$. tabernaemontani-T. latifolia stand that characterizes the interior deep marsh; elevations for this cover type extended to the lake bottom (1,946.09 m; USFWS, unpublished data). Most Baltic rush plots occurred between the annual drawdown and median spring high levels. Moist meadow, alkali, mesic meadow,

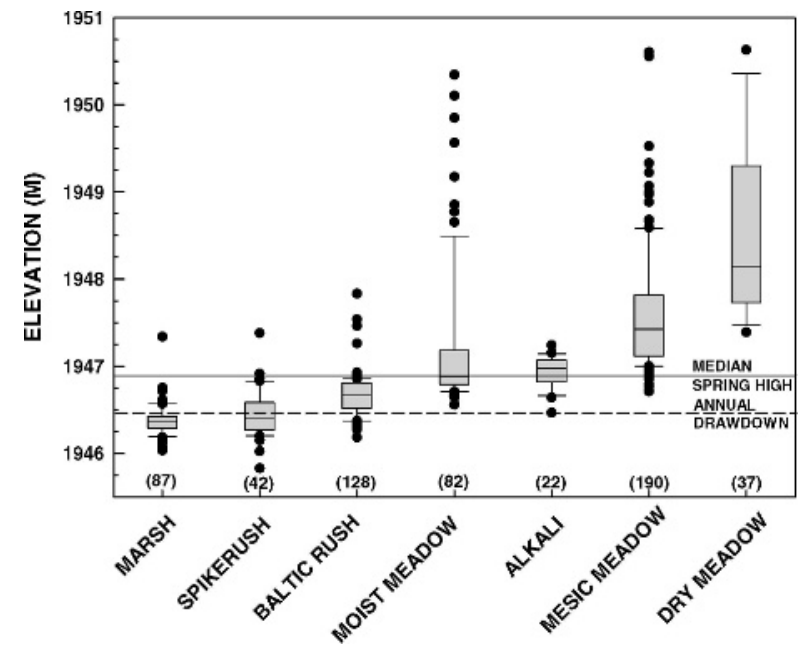

Figure 2. Elevations of sample plots occurring in each of the 8 cover types occurring in 11 experimental fields (excludes Field 18B) at Grays Lake National Wildlife Refuge, Idaho. Box plots show median (horizontal line in box), $25^{\text {th }}$ and $75^{\text {th }}$ percentiles (shaded box), $10^{\text {th }}$ and $90^{\text {th }}$ percentiles (bars with whiskers) and outliers (dots). Sample sizes are indicated in parentheses. 

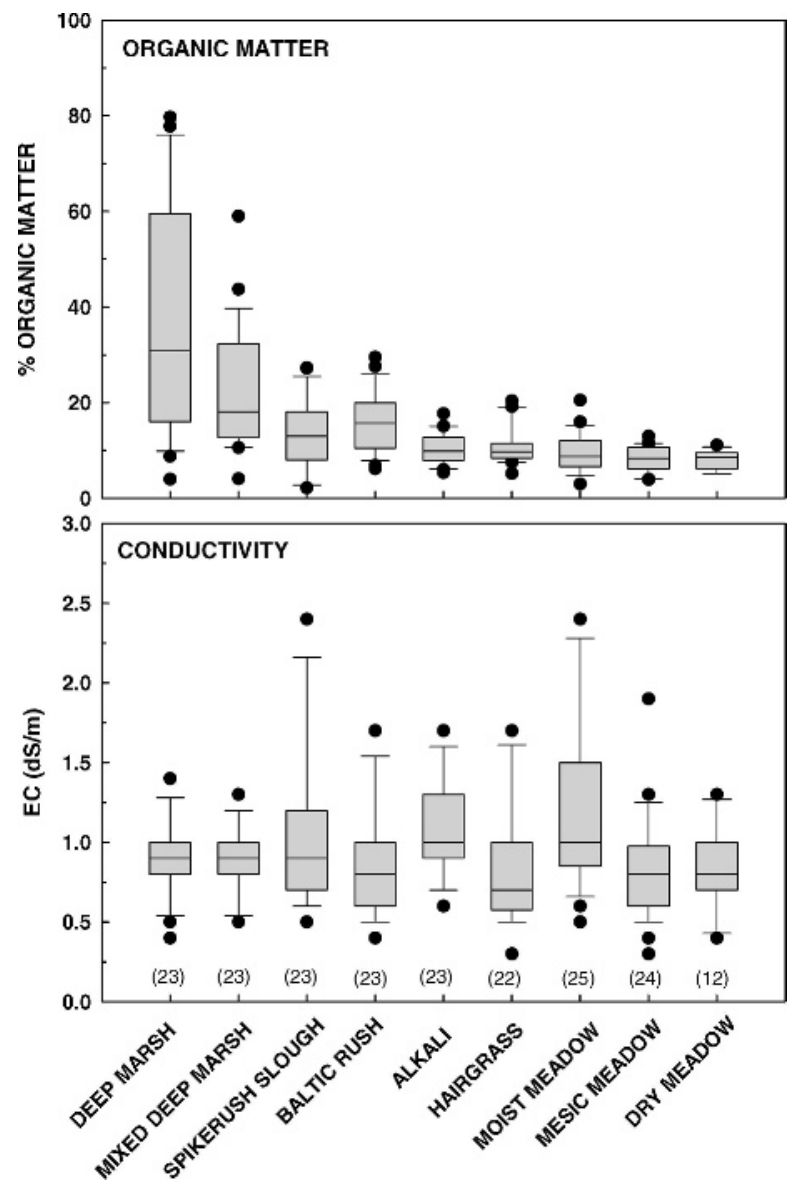

Figure 3. Percent organic matter and conductivity (dS/ $\mathrm{m}$ ) in soils sampled across nine cover types at Grays Lake, Idaho, in August 2000. Sample sizes are indicated in parentheses. Three outliers for mesic meadow that occurred $>1,951 \mathrm{~m}$ elevation are not shown.

and dry meadow plots were primarily limited to elevations at or above the median spring water level, and most dry meadow plots were $>0.6 \mathrm{~m}$ above median high water levels. Moist meadow and mesic meadow plots occupied the widest range of elevations.

\section{Soil Characteristics of Plant Communities}

Percent organic matter in wetland soils was highest and most variable in deep marsh and mixed deep marsh plots (Figure 3). It was lowest and least variable in alkali to dry meadow plots. Conductivity tended to be highest in alkali plots and most variable in spikerush slough and moist meadow plots. We noted little variation among cover types in percent sand (median values $=26.0 \%-31.5 \%)$, clay $(17 \%$ $22.5 \%$ ), and silt (45.5\%-58.0\%). Median percent silt was highest (58\%) and percent clay lowest $(17 \%)$ in dry meadow plots.
Response of Plant Community Composition to Treatments

Vegetation community composition change, following the treatments, was not dramatic, but some trends were observed. We inferred changes in communities based on shifts in plant species dominance in treatment plots.

Mixed Deep Marsh. After one year of treatment, $78 \%$ of mixed deep marsh plots shifted toward greater cover by open water and aquatic species (Figure 4; axis 2). In fall-burn fields, 64\% of plots shifted toward species more representative of fresher water conditions (i.e., less saline), whereas $70 \%$ of plots in rotation fields shifted toward more alkaline species (e.g., greater dominance of species such as $J$. balticus, D. caespitosa, or $M$. richardsonis; axis 3). In 2000 , the response was mixed, with about one-third of mixed deep marsh plots apparently shifting back toward the 1998 community ( $\leq 0.5$ change), and $<$ $40 \%$ of plots continuing to have more open water and aquatic species, as seen in 1999. About 55\% of plots in fall-graze fields shifted toward more alkaline, moist meadow conditions, and $75 \%$ of mixed deep marsh plots in fall-burn fields shifted toward species representative of fresher conditions.

Spikerush Slough. Most $(>75 \%)$ of the plots showed modest $(\leq 0.5)$ changes in community composition (Figure 5). There were only three spikerush slough plots in idle fields, and these showed no consistent pattern of change in community composition either one or two years after treatment. After one year of treatment, $>50 \%$ of plots of all active treatments shifted toward greater cover of open water and aquatic species, similar to that noted for mixed deep marsh plots; the trend was strongest $(76 \%)$ for plots that had been grazed. Spikerush slough plots in fall-burn fields shifted toward moist edge and successional species in both years (55\% and 95\%, respectively), while > $95 \%$ of slough plots in rotation fields shifted toward greater cover by freshwater species in both years.

Baltic Rush. Approximately half of Baltic rush plots showed little change $(<0.25)$, but in some plots, changes in community composition were substantial. In the first year following treatment, variability in response was lowest for plots in fallburn fields (except for one outlier) and greatest for those in fall-graze and idle fields (Figure 6). About $60 \%$ of grazed plots and $78 \%$ of idle plots shifted toward more aquatic species and greater dominance of marsh sedges, reflecting a marked decrease in the dominance of Baltic rush. By 2000, $>60 \%$ of all 


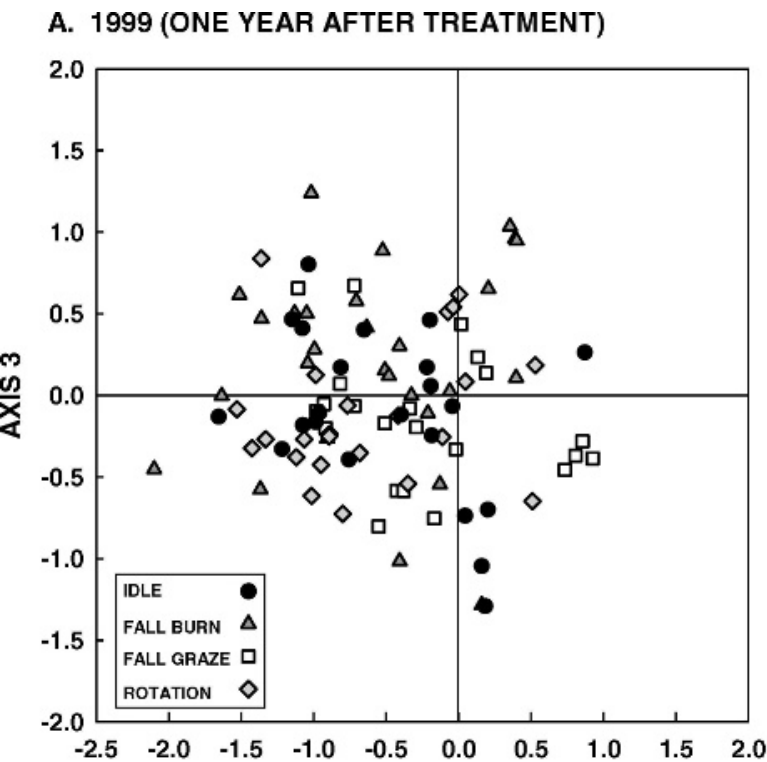

Standing

Open Water

Aquatic Species
B. 2000 (TWO YEARS AFTER TREATMENT)

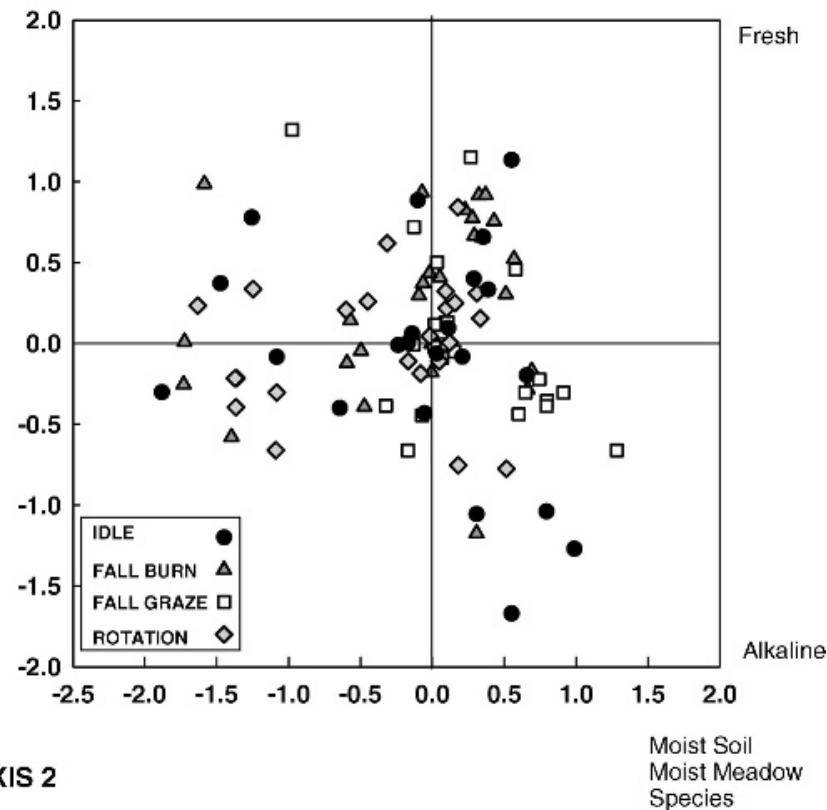

Figure 4. Ordination plots of changes in cover type composition 1 (A) and 2 (B) years after treatment in the mixed deep marsh cover type at Grays Lake National Wildlife Refuge, Idaho. The 0,0 lines in each graph's center indicate no change. Labels assigned to axes indicate directional shifts in dominance by plant species types.

plots showed that marsh species (Eleocharis spp. and Carex spp.) increased noticeably in cover in the moist soil areas, contributing to the reduction in cover by $J$. balticus.
Moist Meadow. Changes in community composition of moist meadow were modest $(\leq 0.5)$ for $>$ $80 \%$ of all plots in both years following treatment (Figure 7). After one year of treatment, about $60 \%$

\section{A. 1999 (ONE YEAR AFTER TREATMENT)}

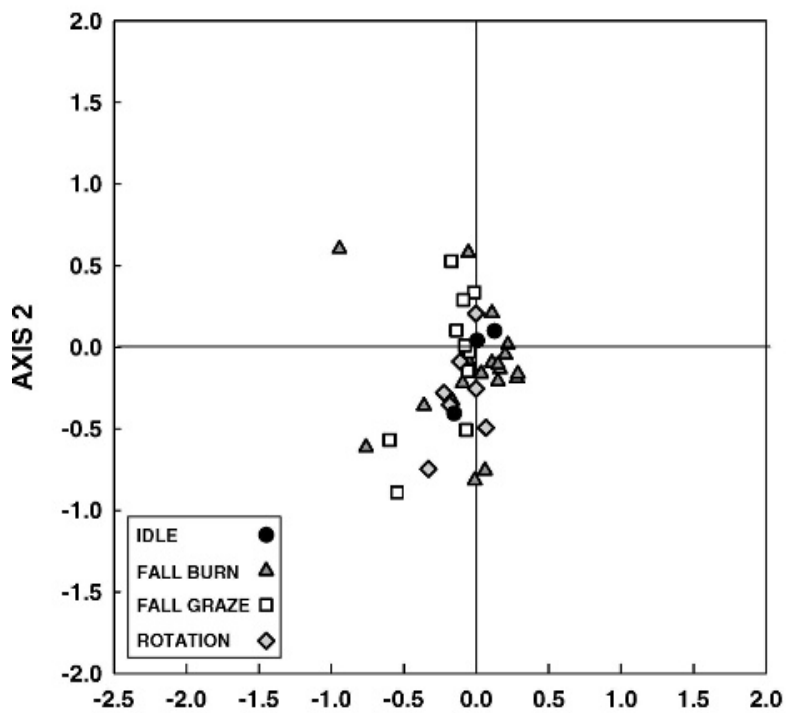

Standing Water or Saturated Soil

Aquatic Species

\section{B. 2000 (TWO YEARS AFTER TREATMENT)}

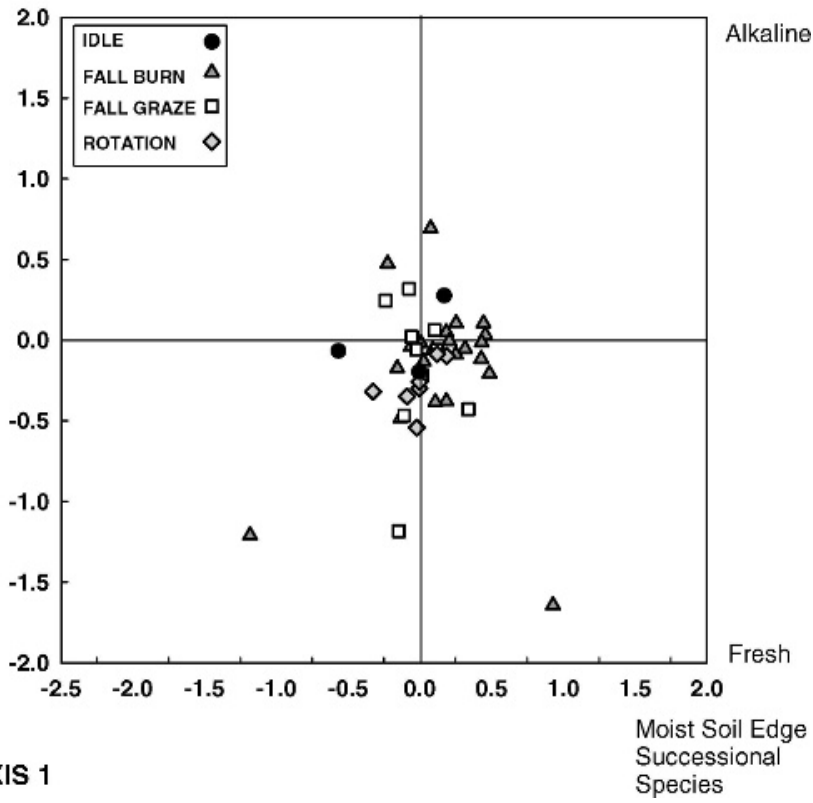

Figure 5. Ordination plots of changes in cover type compostion 1 and 2 years after treatment in the spikerush slough cover type at Grays Lake National Wildlife Refuge, Idaho. The 0,0 lines in each graph's center indicate no change. Labels assigned to axes indicate directional shifts in dominance by types of plant species. 

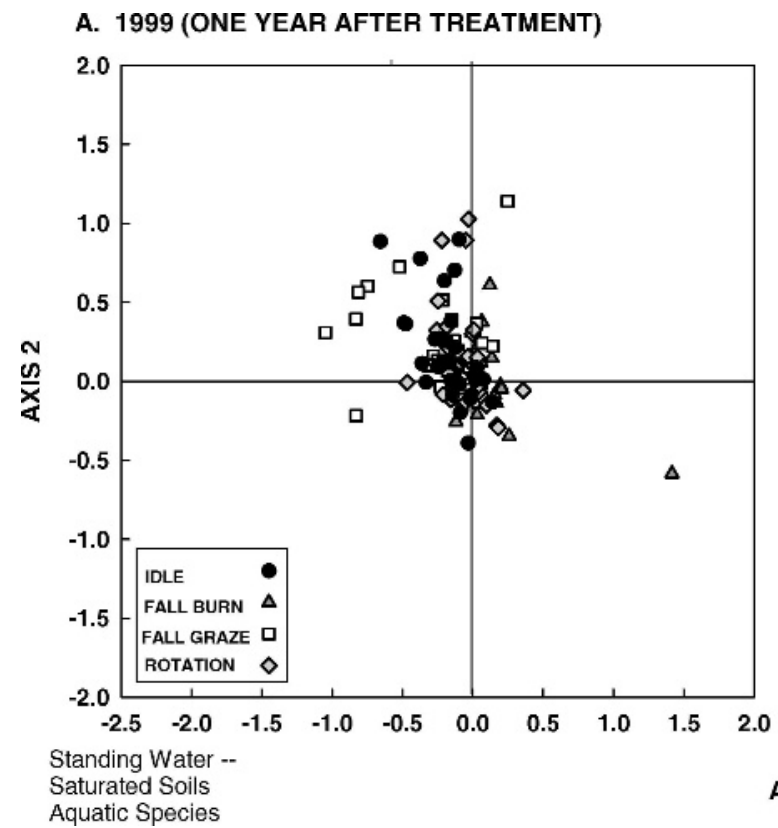

\section{B. 2000 (TWO YEARS AFTER TREATMENT)}

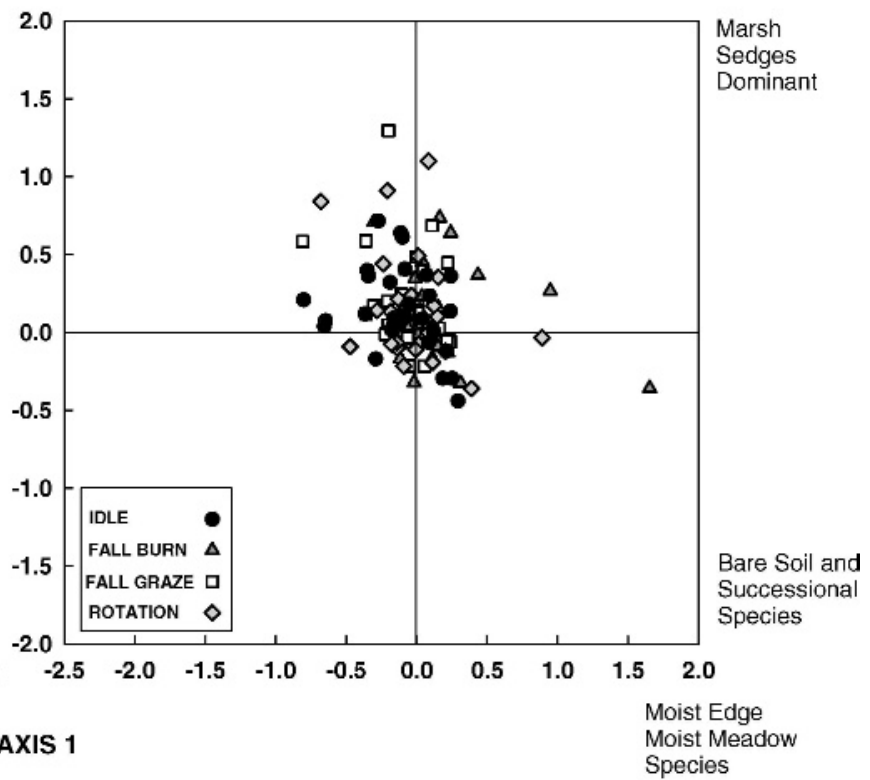

Figure 6. Ordination plots of changes in cover type compostion 1 and 2 years after treatment in the Baltic rush cover type at Grays Lake National Wildlife Refuge, Idaho. The 0,0 lines in each graph's center indicate no change. Labels assigned to axes indicate directional shifts in dominance by types of plant species.

of plots in idle fields shifted toward species associated with moister, fresher conditions. After two years of treatment, there was greater variability and little consistent pattern for any treatment.
Mesic Meadow. All plots in fall-graze and $>80 \%$ of fall-burn treatments had greater cover of woody species (Artemisia incana and $A$. tridentata) after one year of treatment (Figure 8 ). About $70 \%$ of plots in

\section{A. 1999 (ONE YEAR AFTER TREATMENT)}

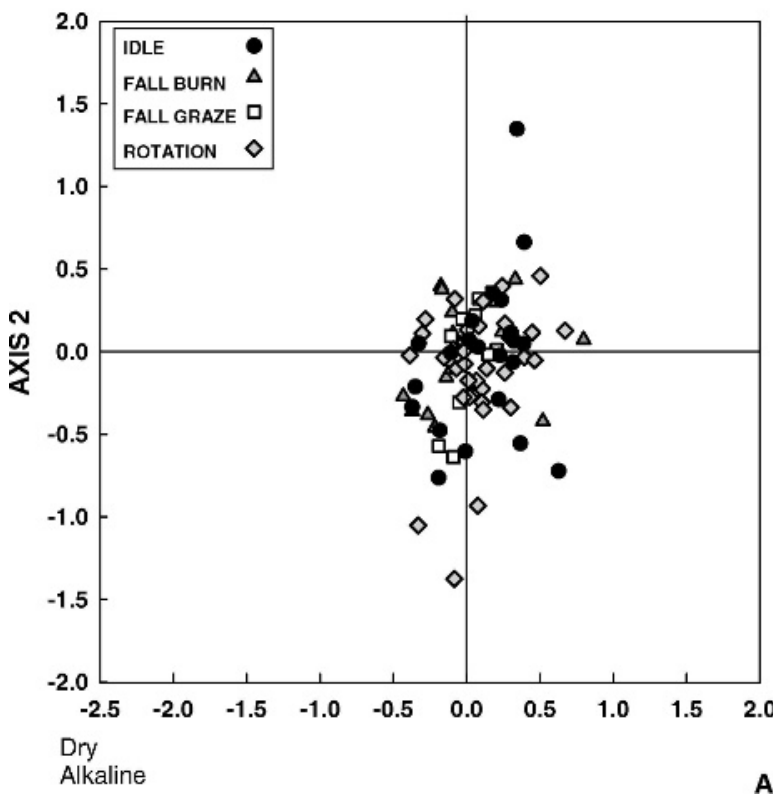

B. 2000 (TWO YEARS AFTER TREATMENT)

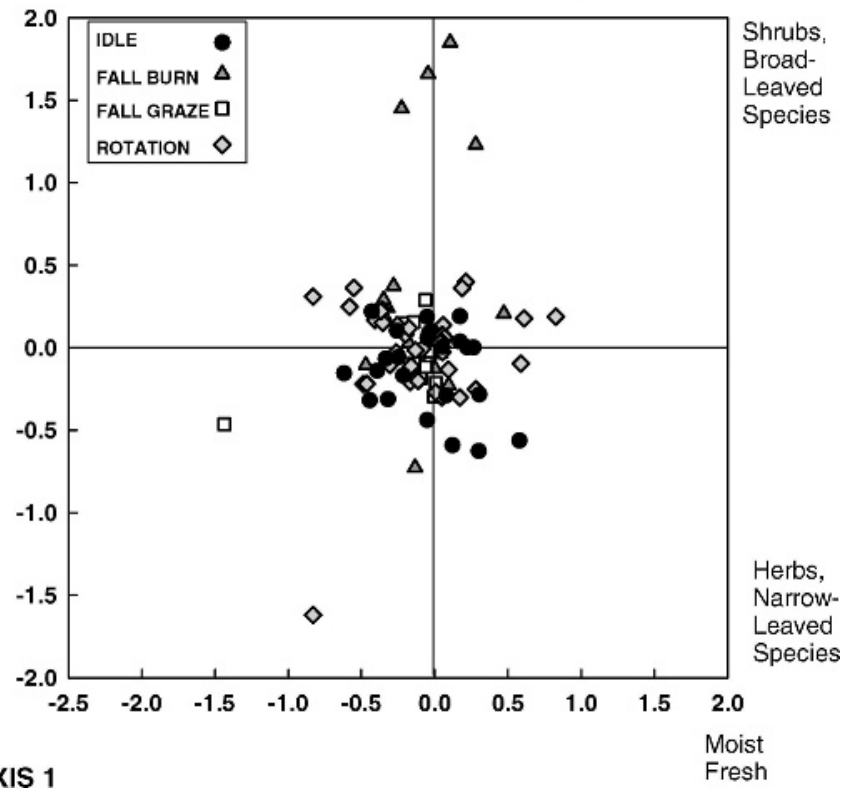

Figure 7. Ordination plots of changes in cover type compostion 1 and 2 years after treatment in the moist meadow cover type at Grays Lake National Wildlife Refuge, Idaho. The 0,0 lines in each graph's center indicate no change. Labels assigned to axes indicate directional shifts in dominance by types of plant species. 

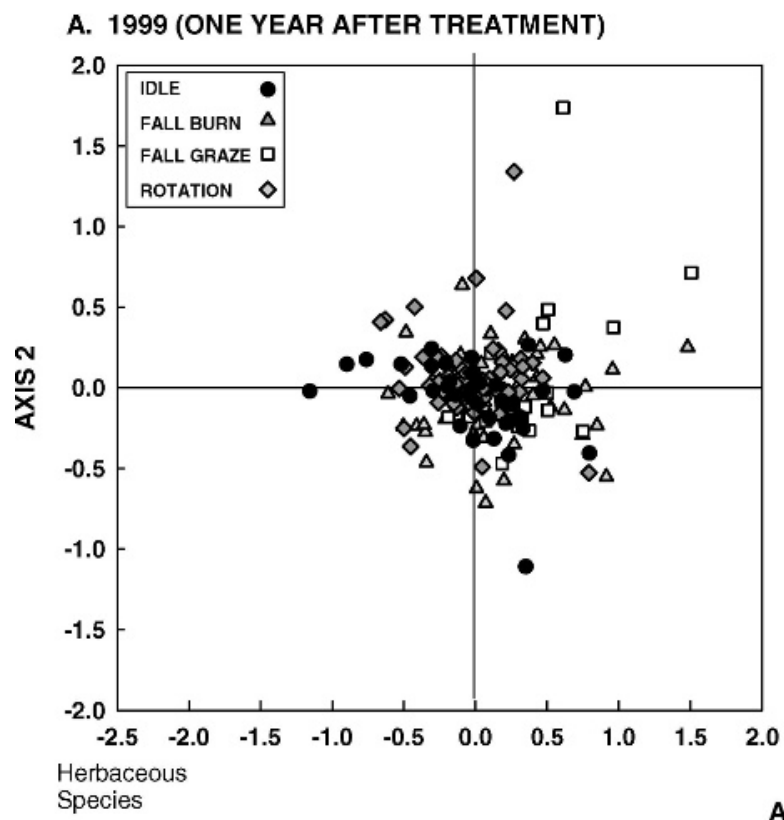

B. 2000 (TWO YEARS AFTER TREATMENT)

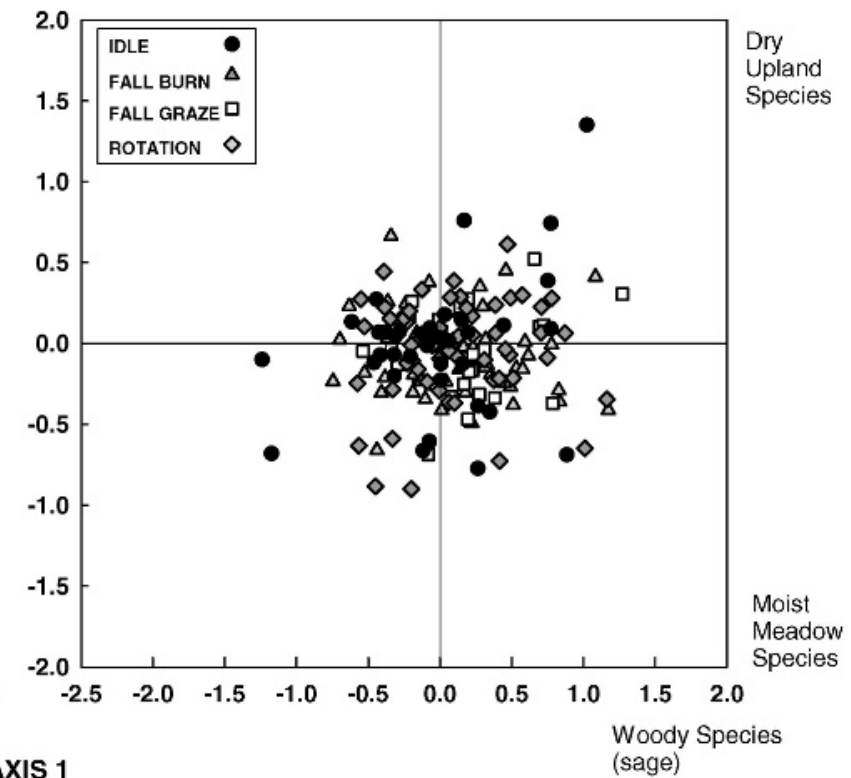

Figure 8. Ordination plots of changes in cover type compostion 1 and 2 years after treatment in the mesic meadow cover type at Grays Lake National Wildlife Refuge, Idaho. The 0,0 lines in each graph's center indicate no change. Labels assigned to axes indicate directional shifts in dominance by types of plant species.

the fall-graze treatment continued to maintain a greater cover of woody species in 2000 . Changes were somewhat greater in 2000 than in 1999.

\section{Response of Plant Biomass to Year and Treatments}

During the two pre-treatment years, mean biomass declined in mesic and dry meadow plots, but increased in deep mixed marsh, Baltic rush, alkali, and moist meadow (all fields included; Table 2). Biomass in spikerush slough plots did not change between years. In idle fields, where consistent treatment allowed comparison among all four years, mean biomass differed among years only for plots in Baltic rush $\left(\mathrm{F}_{3,112}=4.18, \mathrm{P}=0.008\right)$ and moist meadow $\left(\mathrm{F}_{3,88}=3.73, \mathrm{P}=0.014\right)$ (Table 3). In
Baltic rush plots, mean biomass was substantially lower in 1997 than in 1998 or 1999. In moist meadow plots, mean biomass in 1998 was higher than mean biomass in 2000 . We did not examine annual differences in spikerush slough and alkali because of small sample sizes (three and one plots in idle fields, respectively).

After one year of treatment (1998-1999; Figure 9A), changes in biomass differed among treatments for plots in mixed deep marsh $\left(\mathrm{F}_{3,95}=5.20, \mathrm{P}\right.$ $=0.002)$, spikerush slough $\left(F_{3,37}=5.12, \mathrm{P}=0.005\right)$, mesic meadow $\left(\mathrm{F}_{3,181}=6.98, \mathrm{P}<0.001\right)$, and dry meadow $\left(\mathrm{F}_{2,34}=7.07, \mathrm{P}=0.003\right)$. Change in biomass in idle plots, which showed little change, differed from changes in plots in mixed deep marsh (biomass declined in fall-burn and rotation fields),

Table 2. Aboveground plant biomass $\left(\mathrm{g} / \mathrm{m}^{2}\right)$ (LSMEANS $\pm \mathrm{SE}$ ) in seven cover types at Grays Lake National Wildlife Refuge, Idaho, during 1997 and 1998 (pre-treatment). Biomass differed among years for all cover types except spikerush slough and alkali; years having different letters within cover type differed among years $(\mathrm{P}<0.05$, ANOVA).

\begin{tabular}{|c|c|c|c|c|c|c|c|c|c|c|}
\hline \multirow[b]{2}{*}{ Cover type } & \multicolumn{4}{|c|}{1997} & \multicolumn{4}{|c|}{1998} & \multirow[b]{2}{*}{$\mathrm{F}$} & \multirow[b]{2}{*}{$\mathrm{P}$} \\
\hline & $\mathrm{n}^{\mathrm{a}}$ & Mean & $\mathrm{SE}$ & & $\mathrm{n}$ & Mean & $\mathrm{SE}$ & & & \\
\hline Mixed deep marsh & 95 & 433.3 & 24.5 & A & 99 & 591.7 & 24.0 & $\mathrm{~B}$ & 21.37 & $<0.001$ \\
\hline Spikerush slough & 41 & 354.3 & 30.2 & & 41 & 429.4 & 30.2 & & 3.08 & 0.083 \\
\hline Baltic rush & 117 & 333.5 & 15.5 & A & 118 & 486.0 & 15.5 & $\mathrm{~B}$ & 48.28 & $<0.001$ \\
\hline Alkali & 23 & 280.0 & 19.5 & A & 23 & 348.8 & 19.5 & $\mathrm{~B}$ & 6.20 & 0.017 \\
\hline Moist meadow & 87 & 302.0 & 16.5 & A & 87 & 388.7 & 16.4 & $\mathrm{~B}$ & 13.87 & $<0.001$ \\
\hline Mesic meadow & 183 & 347.8 & 9.2 & A & 186 & 307.3 & 9.1 & B & 9.79 & 0.002 \\
\hline Dry meadow & 37 & 425.0 & 29.1 & A & 37 & 288.3 & 29.1 & $\mathrm{~B}$ & 11.06 & 0.001 \\
\hline
\end{tabular}

${ }^{\mathrm{a}}$ Number of plots 


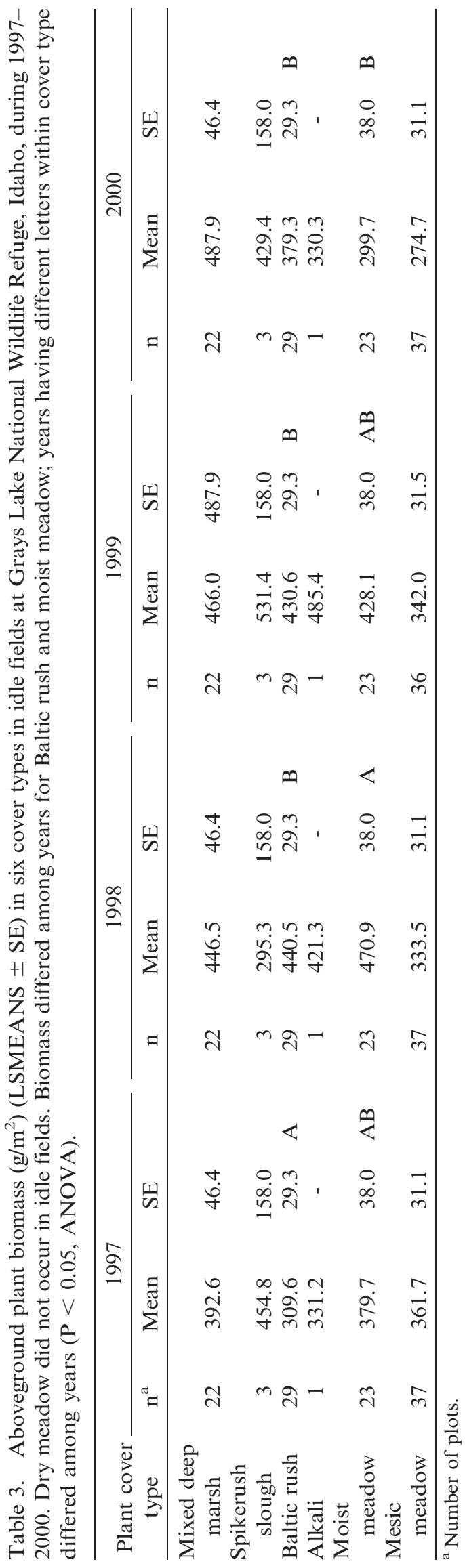

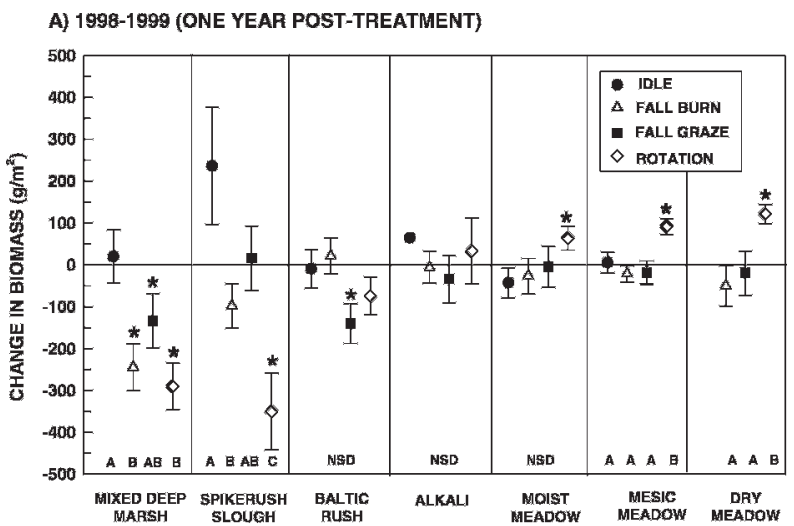
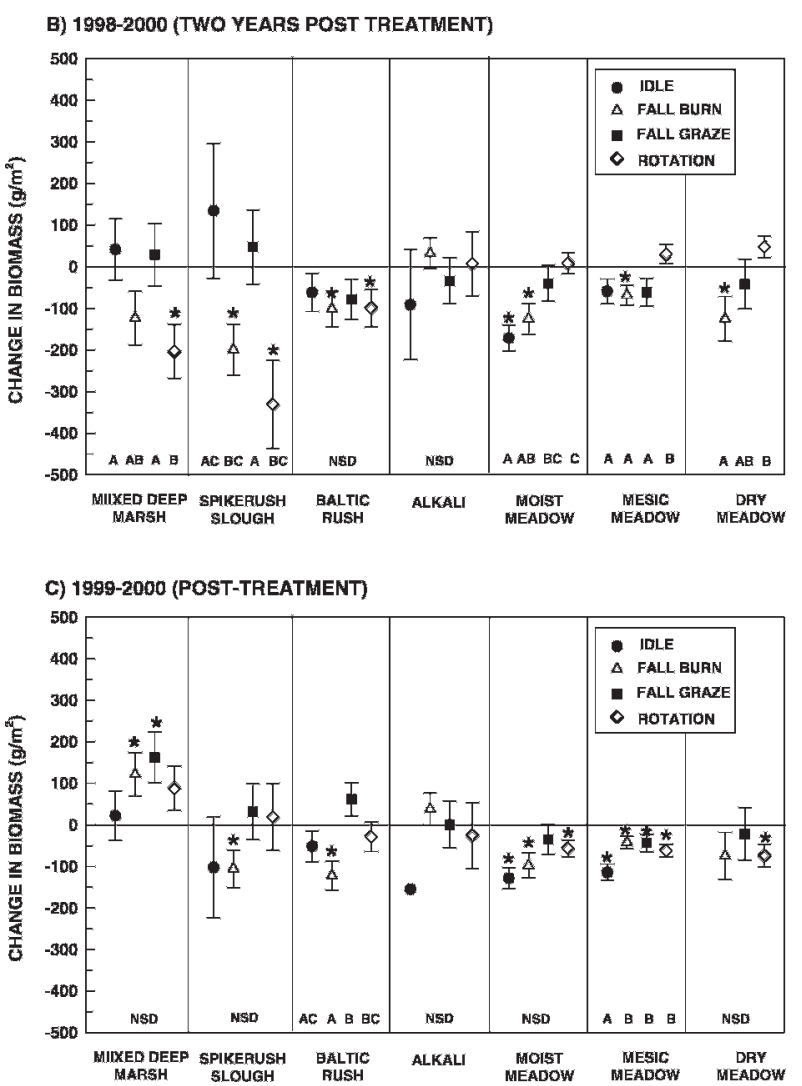

Figure 9. Mean change in aboveground biomass $\pm \mathrm{SE}$ $\left(\mathrm{g} / \mathrm{m}^{2}\right)$ between sequential years, by plant cover type and treatment, at Grays Lake National Wildlife Refuge, Idaho: A) 1997-1998 (pre-treatment years), B) 19981999 (pre- to post-treatment year); and C) 1999-2000 (2 post-treatment years). Asterisks above error bars indicate the mean differed significantly from $0(\mathrm{P}<0.05)$. Letters within each cover type indicate significant differences $(\mathrm{P}<$ 0.05; ANOVA) among treatments; NSD $=$ no significant difference were detected among treatments $(P>0.05)$. See Table 2 for sample sizes.

spikerush slough (biomass declined in fall-burn and rotation fields), and mesic meadow and dry meadow (biomass increased in rotation fields, following one year of summer grazing). 
Patterns of changes in biomass and differences among treatments differed after two years of treatment (1998-2000); all differences from 19982000 were negative (Figure 9B). Biomass remained lower than 1998 levels for the second year in mixed deep marsh plots of rotation fields and spikerush slough plots of fall-burn and rotation fields, despite one year of rest in both treatments. Differences among treatments $(\mathrm{P}<0.05)$ were detected in mixed deep marsh $\left(\mathrm{F}_{3,95}=2.95, \mathrm{P}=0.036\right)$, spikerush slough $\left(\mathrm{F}_{3,37}=3.83, \mathrm{P}=0.017\right)$, moist meadow $\left(\mathrm{F}_{3,83}=7.70, \mathrm{P}<0.001\right)$, and mesic meadow $\left(\mathrm{F}_{3,182}\right.$ $=3.66, \mathrm{P}=0.014)$. Although change in biomass of idle plots changed little from 1998-2000 (with the exception of moist meadow, which declined), biomass in deep mixed marsh of rotation fields and fallburn plots of spikerush slough fields declined. In the driest cover types, change in biomass was least in rotation fields, and differed from idle fields in moist and mesic meadow. Moist meadow plots in fallgrazed fields also showed less change in biomass than in idle fields.

We also detected some differences among treatments between 1999 and 2000 (Figure 9C); during this period, fall-burn and rotation fields were idled and fall-graze fields continued to be grazed. We detected differences among treatments for change in biomass only for Baltic rush $\left(\mathrm{F}_{3,116}=4.16, \mathrm{P}=\right.$ $0.008)$ and mesic upland $\left(\mathrm{F}_{3,185}=3.14, \mathrm{P}=0.026\right)$ cover types. In Baltic rush plots, changes in biomass were positive for plots in fall-grazed fields but negative for plots in idle fields. In mesic upland, biomass declined in all treatments, and the decline in plots of idle fields was greater than declines in the other treatments.

\section{DISCUSSION}

Our study compared community composition and biomass by plant cover type in 1998, which reflected $\geq 3$ years of idle conditions, to 1999 and 2000, following one and two years of active management treatments. The years of idling before treatment should have provided reasonable time for litter to build up and plants to colonize bare ground that may have resulted from earlier grazing. In the two-year period following treatments, we detected small to modest changes in species composition. That we found few substantial impacts of treatments on community composition one to two years after treatment is not surprising given the brief time period. Vegetation responses can be slow, with changes still occurring 5-25 years after treatments are imposed (Volland 1978, Kauffman et al. 1983, Dobkin et al. 1998, Humphrey and Patterson 2000).
Moreover, most of the cover types were dominated by perennial species such as J. balticus or Carex spp., which persist primarily through vegetative growth and tend to have lower seed production than annuals or biennials and, therefore, would be slow to re-colonize or increase (van der Valk and Davis 1979, Dobkin et al. 1998). Poa pratensis, the dominant species in drier cover types, tolerates a wide range of soil moisture conditions (Weixelman et al. 1996) and tolerates or increases under grazing but remains unchanged in the absence of grazing (Schulz and Leininger 1990, Green and Kauffman 1995, Martin and Chambers 2001). We did note, however, that $P$. pratensis was quite lush in moist sites while its stature in drier sites was diminutive. Hence, community composition in cover types dominated by wetland perennials or $P$. pratensis is unlikely to show marked short-term changes due to either treatment or precipitation. Also, Stohlgren et al. (1999) noted that overlap in species composition increases with spatial scale, which would limit ability to detect differences among treatments at larger landscape scales, such as in our study. Although these results were not unexpected, it was important to verify for refuge managers that the selected treatments did not substantially or negatively impact the plant communities in this montane wetland.

Changes within and across several cover types suggest hydrological conditions were an important factor in plant community responses to treatments. Observed changes were consistent with studies of riparian meadows that link species distribution and assemblages to temporal variation in water-table depth, duration of flooding, and soil redox potential (Castelli et al. 2000, Dwire et al. 2006). In 1999, community composition in six of the 12 cover typetreatment combinations in the three wettest cover types (mixed deep marsh, spikerush slough, and Baltic rush) changed toward more cover by open water and aquatic species. Such species were obligate wetland species and likely most tolerant of prolonged anoxic conditions (Dwire et al. 2006). We believe this reflects the impact of four years (19961999) of above-average spring water levels (USFWS, unpublished data). This shift in community composition was weaker in 2000 , but showed some evidence of persistence in some mixed deep marsh plots for both grazing treatments, suggesting grazing and trampling by cattle may maintain or enhance trends toward more open water conditions. In the moist meadow cover type, the shift toward greater cover of species indicative of fresh conditions (low alkalinity) may also be indicative of the four-year period of high water conditions. The reversal in 
community changes in moist meadow plots from 1998-1999 and 1998-2000 demonstrates the transitional position of this cover type relative to water table depth and soil moisture conditions. In 1999, moist meadow plots shifted toward greater cover of species representative of fresh conditions, whereas by 2000 those plots had reversed toward greater cover of species representative of drier, alkaline conditions.

Grazing and associated trampling impacts on rhizomatous species may have contributed to shifts in community composition in mesic meadow, Baltic rush, and mixed deep marsh communities. In mesic meadow, selective grazing on herbs may have contributed to the greater cover by $A$. tripartita and $A$. cana, and less cover by herbaceous species in fields that had been grazed the previous summer (when forbs were still green) compared to fall-burn or fall-graze plots. This concurs with Roath and Kruger's (1982) findings of lower cattle use of the herbaceous vegetation in wet meadows in Oregon when grazing was deferred until mid-August. NoyMeir et al. (1989) noted that as grazing intensity and extent increased from light to moderate, dominant species were reduced and suppressed, altering competition and environmental conditions for other species to respond. In mixed deep marsh plots, reduced litter cover and repeated trampling damage to rhizomes of dominant marsh species (e.g., $T$. latifolia, $S$. tabernaemontani, and $J$. balticus) in fields that were fall-grazed both years may have reduced the competitive abilities of those species and enhanced the opportunities for moist meadow species. Reduced litter cover and increased exposed soil might enhance opportunities for germination, while competitive abilities of mature plants have negatively impacted by grazing (Reynolds 1999). The potential for trampling damage to root crowns is higher in the softer, peaty substrates of the marsh; cattle tend not to graze in this very wet community until late in the year when more preferred vegetation in drier cover types has been consumed (Roath and Krueger 1982, Austin et al. 2004). Livestock activity in the Baltic rush cover type was minimal and also tended to occur later in the year, when conditions were drier. Since cattle consumption of $J$. balticus was minimal (Austin et al. 2004), trampling was likely the main factor reducing its percent cover and competitive abilities relative to other species there. Trampling can also result in greater exposure of soils (i.e., reduced litter cover), leading to higher surface soil temperatures, increased evaporation, and the potential for more alkaline conditions, as indicated in grazed mixed deep marsh plots. The trend toward more alkaline- tolerant species was not apparent the second year for mixed deep marsh plots that had been grazed only in summer 1998, despite lower water levels and summer precipitation.

We consider the treatments applied in this study to be moderate; therefore, it is not surprising that results showed small or moderate changes in plant community composition and biomass. Although fires did remove most residual vegetation, fires were conducted during the fall dormant season and did not seem hot enough to kill root crowns or burn into the substrate. Removal of litter cover and persistence of blackened soils into the following spring would have enhanced conditions for germination and seedling establishment (Reynolds 1999). Frequent, dormant-season burning in seasonally or semipermanently flooded wetlands usually has minimal effects on community composition (Schmalzer et al. 1991, Boyd et al. 1993, Gabrey and Afton 2001), although burning may temporarily stimulate forbs (Bowles et al. 1996, Middleton 2002). Fire may have stimulated growth in $J$. balticus, partially mitigating the effects of prolonged high-water conditions as noted above. Cover of J. balticus was impacted least by fall-burning $(-10.6 \pm 3.2 \%$ [SE]); declines in cover for this species were greater in fallgraze $(-36.9 \pm 3.2 \%)$, idle $(-22.9 \pm 3.1 \%)$, and rotation $(-18.4 \pm 3.1 \%)$ fields. Fall and summer grazing treatments in this study were moderate to heavy, similar to those reported for other wet meadows (Roath and Krueger 1982, Kauffman et al. 1983, Ratliff and Westfall 1987, Schulz and Leininger 1990), but only a small area received very heavy use. Very heavy grazing intensities, which occurred in only small areas of most of our fields, likely would increase the extent of bare ground and trampling impacts (e.g., soil compaction and damage to root crowns) and hence result in greater shifts in community composition towards annual forbs or invasive species (Leege et al. 1981, Green and Kauffman 1995, Dobkin et al. 1998, Humphrey and Patterson 2000, Martin and Chambers 2001).

Historical land uses and water management play an important role in determining the composition of current plant communities and how plant communities responded to the management treatments applied in this study. The dominance of $B$. inermis and $P$. pratensis in mesic and dry meadow, and more frequent occurrence of introduced species in the drier cover types, may reflect past grazing, cultivation, and seeding activities. The plant communities of Grays Lake likely are tolerant to annual grazing, a disturbance that has occurred in the valley for $>$ 100 years, and hence would show little change with additional grazing after only a few years of idling 
(Reynolds 1999). Similarly, water levels have been managed very consistently for $>40$ years, limiting seasonal and annual stochasticity needed for healthy wetland processes and more dynamics communities (Mitsch and Gosselink 2000). In mesic and dry meadows, plant communities have been altered by past seeding of Bromus spp. and other cultivated varieties as well as persistent disturbance by grazing. Idle, the only treatment not historically occurring in the valley since settlement, today occurs only on a small proportion of refuge lands. Separating the effects of historical land uses from environmental factors would require long-term application of treatments and monitoring (e.g., $\geq 10$ years) over a series of wet and dry periods.

\section{Response of Biomass to Year and Treatment Effects}

Biomass tended to be highest in wetter cover types but varied among years, similar to trends found in other montane or riparian wetland studies (Gorham and Somers 1973, Bernard 1974, Leege et al. 1981, Korpela 1992, Dwire et al. 2004). Comparisons of mean biomass between pre-treatment years, and comparisons of changes in biomass between active and idle treatments, indicate that precipitation and water levels (year effects) have a strong influence on biomass, and that there is an interaction among cover types and treatment impacts.

During the pre-treatment years, mean biomass increased in wetter cover types, but declined in mesic and dry meadows. These changes probably are related to seasonal precipitation patterns. Precipitation during July and August 1997 was above the long-term average (Idaho State Climate Data Services 2004), and likely supported high biomass and late-season production in mesic and dry meadow plots. Above-average precipitation during May and June 1998, combined with above-average high water levels, likely supported above-average soil moisture conditions for wetter cover types for the entire growing season that year. For cover types at higher elevations, soil moisture also would have been above normal in spring, but closer to normal (drier) later in the growing season. Total biomass in montane grasslands and wet meadows can vary substantially between wet and dry years (Mueggler 1983). The patterns documented in our study are consistent with the findings of Korpela (1992), who reported that soil moisture conditions (as influenced by precipitation) strongly influenced biomass in dry bluegrass meadows and depth to water table strongly influenced biomass in wet meadows.

Treatment effects appear most substantial in the wettest and driest cover types, with much less impact on the middle cover types: Baltic rush and alkali. Declines in biomass in active treatments were most apparent in mixed deep marsh and spikerush slough, particularly following fall-burn and rotation treatments. The impacts of one year of fall burning persisted into the second year for spikerush slough plots. Fire often stimulates growth the season after burning (Young 1987, Bernard et al. 1988, Johnson and Knapp 1993, DeBano et al. 1998, Kost and de Steven 2000). However, burning effects in our study seemed to be tempered by declining water conditions, as we found no evidence that fall burning stimulated growth in any cover type when compared to the idle treatment. Growth was stimulated only in drier cover types (moist, mesic, and dry meadows) that were summer grazed (i.e., defoliation during the growing period). Common species in these cover types such as $D$. caespitosa and $P$. pratensis can tolerate or increase with grazing (Leege et al. 1981, Schulz and Leininger 1990, Green and Kauffman 1995, Martin and Chambers 2001). Because there was only one application (year) of summer grazing, we cannot assess whether the biomass decline two years after grazing was due to low precipitation that year or the absence of a defoliation event to maintain higher biomass. Our results demonstrate the need to recognize and consider the interactions among treatment intensity, precipitation, hydrologic patterns, and wetland heterogeneity (plant communities, soil types, and hydrology) when applying management treatments. Longer periods of treatment application and extended monitoring of plant communities and biomass are needed to clarify how management practices might be tailored for key cover types or particular species.

We caution that all changes in biomass are primarily based on a single comparison to one pretreatment year (1998), when biomass was higher than in 1997 for all but mesic and dry meadow cover types. Hence, comparisons between 1998 and subsequent years may result in greater differences in biomass for wetter cover types than for the two drier cover types. Comparison of idle cover across all years indicates significant year-to-year variation, likely driven by precipitation in this dry region of Idaho. Differences in year-to-year responses were seen across cover types as well. Land managers need to be aware that responses of vegetation to management may vary among years, depending on water and climatic conditions.

\section{CONCLUSIONS}

This study provides the first comprehensive documentation of the floristic composition along 
the transition from dry meadows to wetland communities at Grays Lake. Communities were largely dominated by native species, and occurrence of introduced species was low in the wetter cover types. Overall, responses by vegetation to idle and active treatments were small or modest. As found in other studies of riparian or montane wet meadows (Green and Kauffman 1995, Dobkin et al. 1998, Martin and Chambers 2001, Dwire et al. 2006), our results illustrate the spatial and temporal complexity of the transition between dry meadows and wetland habitats, and variable interactions among plant communities, treatments, and annual wetland climatic conditions. Soil moisture, as influenced by hydrology and precipitation, plays a critical role in the distribution of wetland plant communities (Allen-Diaz 1991, Chambers et al. 1999, Castelli et al. 2000) and influences plant responses to management activities (Dobkin et al. 1998, Martin and Chambers 2001). Therefore, changes in hydrology or an area's precipitation patterns, such as seen with long-term drought, are more likely to result in substantial changes in plant communities and function in these montane wetlands than moderate application of grazing or burning. Information from studies of montane riparian wetlands may be useful in predicting changes in montane palustrine wetland communities when hydrology or vegetation is manipulated.

\section{ACKNOWLEDGMENTS}

Funding and support were provided through the U.S. Geological Survey's Quick Response Program and U.S. Fish and Wildlife Service-Region 1. J. Watts, R. Maroney, and P. O'Hearn provided assistance in collection of plant cover data. Other field assistance was provided by J. Brennan, K. Cain, M. Crabb, R. Crawford, K. Dickenson, B. Edrington, B. Hanson, B. Lorenz, S. Marriot, T. Michaels, R. Mikkelson, C. Pace, T. Perkins, L. Stoby, W. Smith, D. Taylor, A. Wilcox, and A. Zmud. D. Buhl provided statistical assistance. K. Holte, Idaho State University, provided identification of voucher specimens. This manuscript benefited from the constructive comments of K. Dwire, R. Budelsky, J. Chambers, B. Middleton, and R. Sojda.

\section{LITERATURE CITED}

Allen-Diaz, B. H. 1991. Water table and plant species relationships in Sierra Nevada meadows. American Midland Naturalist 126:30-43.

Anderson, E. W. and W. F. Currier. 1973. Evaluating zones of utilization. Journal of Range Management 26:87-91.
Austin, J. E., J. R. Keough, and W. H. Pyle. 2004. Effects of habitat management practices on plant cover types of uplands and wetlands at Grays Lake National Wildlife Refuge, Idaho, 1997-2000. Report submitted to U.S. Fish and Wildlife Service. U. S. Geological Survey, Northern Prairie Wildlife Research Center, Jamestown, ND, USA.

Austin, J. E. and W. H. Pyle. 2004. Nesting ecology of waterbirds at Grays Lake, Idaho. Western North American Naturalist 64:277-92.

Bernard, J. M. 1974. Seasonal changes in standing crop and primary production in a sedge wetland and an adjacent dry oldfield in central Minnesota. Ecology 55:350-59.

Bernard, J. M., D. Solander, and J. Kvet. 1988. Production and nutrient dynamics in Carex wetlands. Aquatic Botany 30:125-47.

Bowles, M., J. McBride, N. Stoynoff, and K. Johnson. 1996. Temporal changes in vegetation composition and structure in a fire-managed prairie fen. Natural Areas Journal 16:275-88.

Boyd, R. S., R. A. Woodward, and G. Walter. 1993. Fire effects on a montane Sierra Nevada meadow. California Fish and Game 79:115-25.

Brower, J., J. Zar, and C. von Ende. 1990. Field and Laboratory for General Ecology, third edition. William C. Brown Publishing, Dubuque, IA, USA.

Castelli, R. M., J. C. Chambers, and R. J. Tausch. 2000. Soilplant relations along a soil-water gradient in Great Basin meadows. Wetlands 20:251-66.

Chambers, J. C., R. R. Blank, D. C. Zamudio, and R. J. Tausch. 1999. Central Nevada riparian areas: physical and chemical properties of meadow soils. Journal of Range Management 52:92-99.

Cronquist, A., A. H. Holmgren, N. H. Holmgren, and J. L. Reveal. 1992-1994. Intermountain Flora. Volumes 1-5. New York Botanical Garden, New York, NY, USA.

DeBano, L. F., D. G. Neary, and P. F. Ffolliott. 1998. Fire Effects on Ecosystems. John Wiley and Sons, Inc., New York, NY, USA.

Dobkin, D. S., A. C. Rich, and W. H. Pyle. 1998. Habitat and avifaunal recovery from livestock grazing in a riparian meadow system of the northwestern Great Basin. Conservation Biology 12:209-21.

Dwire, K. A., J. B. Kauffman, and J. E. Baham. 2006. Plant species distribution in relation to water-table depth and soil redox potential in montane riparian meadows. Wetlands 26:131-46.

Dwire, K. A., J. B. Kauffman, E. N. J. Brookshire, and J. E. Baham. 2004. Plant biomass and species composition along an environmental gradient in montane riparian meadows. Oecologia 139:300-17.

Gabrey, S. W. and A. D. Afton. 2001. Plant community composition and biomass in Gulf Coast Chenier Plain marshes: responses to winter burning and structural marsh management. Environmental Management 27:281-93.

Gammonley, J. H. 1996. Seasonal use of montane wetlands by waterbirds on the Rim of the Colorado Plateau. Ph.D. Dissertation. University of Missouri, Columbia, MO, USA.

Gorham, E. and M. G. Somers. 1973. Seasonal changes in standing crop of two montane sedges. Canadian Journal of Botany 51:1097-1108.

Green, D. M. and J. B. Kauffman. 1995. Succession and livestock grazing in a northeastern Oregon riparian ecosystem. Journal of Range Management 48:307-13.

Greig-Smith, P. 1983. Quantitative Plant Ecology, third edition.. Blackwell Scientific Publications, Oxford, UK.

Hitchcock, C. L. 1973. Flora of the Pacific Northwest; An Illustrated Manual. University of Washington Press, Seattle, WA, USA.

Hoff, T. M. 1993. Effects of cattle grazing on waterfowl nesting cover in Arizona montane wetlands. M.S. Thesis. Northern Arizona University, Tucson, AZ, USA.

Humphrey, J. W. and G. S. Patterson. 2000. Effects of late summer cattle grazing on the diversity of riparian pasture vegetation in an upland conifer forest. Journal of Applied Ecology 37:986-96. 
Idaho State Climate Services. 2004. http://snow.ag.uidaho.edu. Last Accessed 8 Jan 2004

Johnson, S. R. and A. K. Knapp. 1993. The effect of fire on gas exchange and aboveground biomass production in annually vs. biennially burned Spartina pectinata wetlands. Wetlands 13:299-303.

Kauffman, J. B., W. C. Krueger, and M. Vavra. 1983. Effects of late season cattle grazing on riparian plant communities. Journal of Range Management 36:685-91.

Kirby, R. E., J. K. Ringelman, D. R. Anderson, and R. S. Sojda. 1992. Grazing on national wildlife refuges: do the needs outweigh the problems? Transactions of the North American Wildlife and Natural Resources Conference 57:613-26.

Korpela, E. J. 1992. Modeling riparian zone processes: biomass production and grazing. Ph.D. Dissertation. Oregon State University, Corvallis, OR, USA.

Kost, M. A. and D. De Steven. 2000. Plant community responses to prescribed burning in Wisconsin sedge meadows. Natural Areas Journal 20:36-45.

Leege, T. A., D. J. Herman, and B. Zamora. 1981. Effects of cattle grazing on mountain meadows. Journal of Range Management 34:324-28.

Marston, R. A. and J. E. Anderson. 1991. Watersheds and vegetation of the Greater Yellowstone Ecosystem. Conservation Biology 5:338-46.

Martin, D. W. and J. C. Chambers. 2001. Effects of water table, clipping, and species interactions on Carex nebrascensis and Poa pratensis in riparian meadows. Wetlands 21:421-30.

McCune, B. and M. J. Mefford. 1999. PC-ORD. Multivariate Analysis of Ecological Data. Version 4. MJM Software Design, Gleneden Beach, OR, USA.

Middleton, B. 2002. Winter burning and the reduction of Cornus sericea in sedge meadows in southern Wisconsin. Restoration and Management Notes 10:723-30.

Mitchell, W. A. and H. G. Hughes. 1995. Point sampling. Section 6.2.1, U.S. Army Corps of Engineers Wildlife Resources Management Manual, Technical Report EL-95-25.

Mitsch, W. J. and J. G. Gosselink. 2000. Wetlands, third edition. John Wiley and Sons, Inc., New York, NY, USA.

Mueggler, W. F. 1983. Variation in production and development of mountain grasslands in western Montana. U.S. Department of Agriculture, Forest Service, Intermountain Forest and Range Experiment Station Research Paper INT-316.

Noy-Meir, I., N. Gutman, and Y. Kaplan. 1989. Responses of Mediterranean grassland plants to grazing and protection. Journal of Ecology 77:290-310.

Patton, D. R. and B. I. Judd. 1970. The role of wet meadows as wildlife habitat in the southwest. Journal of Range Management 23:272-75

Ratliff, R. D. and S. E. Westfall. 1987. Dry-year grazing and Nebraska sedge (Carex nebrascensis). Great Basin Naturalist 47:422-26.

Reynolds, H. L. 1999. Plant interactions: competition. p. 649-76. In F. I. Pugnaires and F. Valladores (eds.) Handbook of Plant Ecology. Marcel Dokker, Inc., New York, NY, USA.
Roath, L. R. and W. C. Krueger. 1982. Cattle grazing and behavior on a forested range. Journal of Range Management $35: 332-38$

SAS Institute, Inc. 1999. SAS OnlineDoc, Version 8. SAS Institute, Inc., Cary, NC, USA.

SAS Institute. 2002. SAS OnlineDoc, Version 9.1. SAS Institute, Inc., Cary, NC, USA.

Sanders, R. L. 1997. Montane wetland characteristics and waterfowl use on the Routt National Forest, Colorado. M.S. Thesis. University of Missouri, Columbia, MO, USA.

Schmalzer, P. A., C. R. Hinkle, and J. L. Mailander. 1991. Changes in community composition and biomass in Juncus roemerianus Scheele and Spartina bakeri Merr. marshes one year after a fire. Wetlands 11:67-86.

Schulz, T. T. and W. C. Leininger. 1990. Differences in riparian vegetation structure between grazed areas and exclosures. Journal of Range Management 43:295-98.

Steel, P. E. 1952. Factors affecting waterfowl production at Gray's Lake, Idaho. M.S. Thesis. University of Idaho, Moscow, ID, USA.

Stohlgren, T. J., L. D. Schell, and B. Vanden Heuvel. 1999. How grazing and soil quality affect native and exotic plant diversity in Rocky Mountain grasslands. Ecological Applications 9:45-64.

U.S. Fish and Wildlife Service. 1982. Master plan report for Grays Lake National Wildlife Refuge, Wayan, Idaho. U.S. Fish and Wildlife Service, Portland, OR, USA.

van der Valk, A. G. and C. B. Davis. 1979. A reconstruction of the recent vegetational history of a prairie marsh, Eagle Lake, Iowa, from its seed bank. Aquatic Botany 6:29-51.

Volland, L. A. 1978. Trends in standing crop and species composition of a rested Kentucky bluegrass meadow over an 11 year period, p. 526-29. In D. N. Hyder (ed.) Proceedings International Range Congress. Denver, Colorado, USA.

Weixelman, D. A., D. C. Zamudio, and K. A. Zamudio. 1996. Central Nevada Riparian Field Guide. U.S. Department of Agriculture, Forest Service Region 4 Ecology 96-01. Intermountain Region, Ogden, UT, USA.

Western Regional Climate Center. 2002. Idaho climate summaries. Henry, Idaho (104230). National Oceanographic and Atmospheric Administration, Western Region Climate Center, Reno, NV. http://www.wrcc.dri.edu/cgi-bin/cliMAIN.pl?idhenr. (Vers25 Jan03).

Windell, J. T., B. E. Willard, D. J. Cooper, S. Q. Foster, C. F. Knud-Hanson, L. P. Rink, and G. N. Kiladis. 1986. An ecological characterization of Rocky Mountain montane and subalpine wetlands. U.S. Fish and Wildlife Service Biological Report 86(11).

Wishart, D. 1969. An algorithm for hierarchical classification. Biometrics 25:165-70.

Young, R. P. 1987. Fire ecology and management in plant communities of Malheur National Wildlife Refuge, southeastern Oregon. Ph.D. Dissertation. Oregon State University, Corvallis, OR, USA.

Manuscript received 2 March 2006; accepted 5 March 2007. 